\title{
Aillikites and Alkali Ultramafic Lamprophyres of the Beloziminsky Alkaline Ultrabasic-Carbonatite Massif: Possible Origin and Relations with Ore Deposits
}

\author{
Igor Ashchepkov 1,*(1), Sergey Zhmodik ${ }^{1,2}$, Dmitry Belyanin ${ }^{1,2}{ }^{\oplus}$, Olga N. Kiseleva ${ }^{1}$, \\ Nikolay Medvedev ${ }^{3}$, Alexei Travin ${ }^{1,2}{ }^{-1}$, Denis Yudin ${ }^{1}$, Nikolai S. Karmanov ${ }^{1}$ and \\ Hilary Downes ${ }^{4}$ \\ 1 Sobolev V.S. Institute of Geology and Mineralogy SB RAS, Novosibirsk 630007, Russia; \\ zhmodik@igm.nsc.ru (S.Z.); bel@igm.nsc.ru (D.B.); kiseleva_on@igm.nsc.ru (O.N.K.); \\ travin@igm.nsc.ru (A.T.); yudin@igm.nsc.ru (D.Y.); krm@igm.nsc.ru (N.S.K.) \\ 2 Faculty of Geology and Geophysics, Novosibirsk State University, Novosibirsk 630090, Russia \\ 3 Nikolaev Institute of Inorganic Chemistry SB RAS, Novosibirsk 630090, Russia; medvedev@niic.nsc.ru \\ 4 Department of Earth and Planetary Sciences, Birkbeck University of London, London WC1E 7HX, UK; \\ h.downes@ucl.ac.uk \\ * Correspondence: igor.ashchepkov@igm.nsc.ru; Tel.: +7-9139872605
}

Received: 19 March 2020; Accepted: 27 April 2020; Published: 29 April 2020

\begin{abstract}
The 650-621 Ma plume which impinged beneath the Siberian craton during the breakup of Rodinia caused the formation of several alkaline carbonatite massifs in craton margins of the Angara rift system. The Beloziminsky alkaline ultramafic carbonatite massif (BZM) in the Urik-Iya graben includes alnöites, phlogopite carbonatites and aillikites. The Yuzhnaya pipe (YuP) 645 Ma and the 640-621 Ma aillikites in BZM, dated by ${ }^{40} \mathrm{Ar} /{ }^{39} \mathrm{Ar}$, contain xenoliths of carbonated sulfide-bearing dunites, xenocrysts of olivines, Cr-diopsides, Cr-phlogopites, Cr-spinels ( $\mathrm{P} \sim 4-2 \mathrm{GPa}$ and $\mathrm{T} \sim 800-1250{ }^{\circ} \mathrm{C}$ ) and xenocrysts of augites with elevated HFSE, $\mathrm{U}$, Th. Al-augites and kaersutites fractionated from $\mathrm{T} \sim 1100-700^{\circ} \mathrm{C}$ along the $90 \mathrm{~mW} / \mathrm{m}^{2}$ geotherm. Higher T trend for Al-Ti augite, pargasites, Ti-biotites series (0.4-1.5 GPa) relate to intermediate magma chambers near the Moho and in the crust. Silicate xenocrysts show $\mathrm{Zr}-\mathrm{Hf}$, Ta- $\mathrm{Nb}$ peaks and correspond to carbonate-rich magma fractionation that possibly supplied the massif. Aillikites contain olivines, rare $\mathrm{Cr}$-diopsides and oxides. The serpentinites are barren, fragments of ore-bearing Phl carbonatites contain perovskites, Ta-niobates, zircons, thorites, polymetallic sulphides and Ta-Mn-Nb-rich magnetites, ilmenites and Ta-Nb oxides. The aillikites are divided by bulk rock and trace elements into seven groups with varying HFSE and LILE due to different incorporation of carbonatites and related rocks. Apatites and perovskites reveal remarkably high LREE levels. Aillikites were generated by $1-0.5 \%$ melting of the highly metasomatized mantle with ilmenite, perovskite apatite, sulfides and mica, enriched by subduction-related melts and fluids rich in LILE and HFSE. Additional silicate crystal fractionation increased the trace element concentrations. The carbonate-silicate P-bearing magmas may have produced the concentration of the ore components and HFSE in the essentially carbonatitic melts after liquid immiscibility in the final stage. The mechanical enrichment of aillikites in ore and trace element-bearing minerals was due to mixture with captured solid carbonatites after intrusion in the massif.
\end{abstract}

Keywords: carbonatite aillikites; mantle; rare metals; metasomatism; subduction; plume

\section{Introduction}

The aillikitic rock series was recently divided from the ultramafic lamprophyres [1,2]. The special feature of aillikites is that they are intermediate between carbonatites, kimberlites and alkaline lamprophyres. They form a rather long compositional series, with a wide range of mineral compositions. 
Carbonatite alkaline ultramafic complexes of various types are common within continental plate settings [2-8] but plume-related complexes may be found in various environments. They are commonly located in the continental margins like Siberia and Greenland [9,10] (Figure 1) or in global rift zones like Brazil [11,12]. Very often, various ultramafic and mafic lamprophyric rocks including alnöites and aillikites are associated with the ultramafic rocks like kimberlites type I and II [13]. However, aillikites are a separate carbonatite-rich alkaline ultramafic rocks series $[1,13]$. Sometimes ultramafic lamprophyres trace the convergent margins including subduction zones [14].

The time span for the aillikites in magmatic evolution of the Earth is very wide. Alkaline lamprophyres associated with carbonatites appeared around 2.6 Ga [15] which corresponds to the re-arrangements of mantle convection and the onset of the wide appearance of alkaline mantle rocks [16,17]. Early Proterozoic lamprophyres in the Fennoscandian shield [18] are associated with carbonatites and aillikites associated with the 1.1 By kimberlite plume event in India [5] and in South Africa [19]. Many aillikites and carbonatite complexes trace the last events of the Rodinia breakup into the Northern group of continents [20,21]. Aillikites also accompany most plume events in Paleozoic time in Devonian [22,23] as well as Permo-Triassic superplume [24,25] and in later plume events in Late Cretaceous [26,27] and Eocene [28] periods.

The origin of the aillikitic lamprophyres is suggested to be $1-3 \%$ melting of carbonated metasomatic mantle of MARID type [29]. Experiments show that aillikite magmas may appear at pressures of 6-3 GPa from the alkaline- and carbonate -rich sources [30].

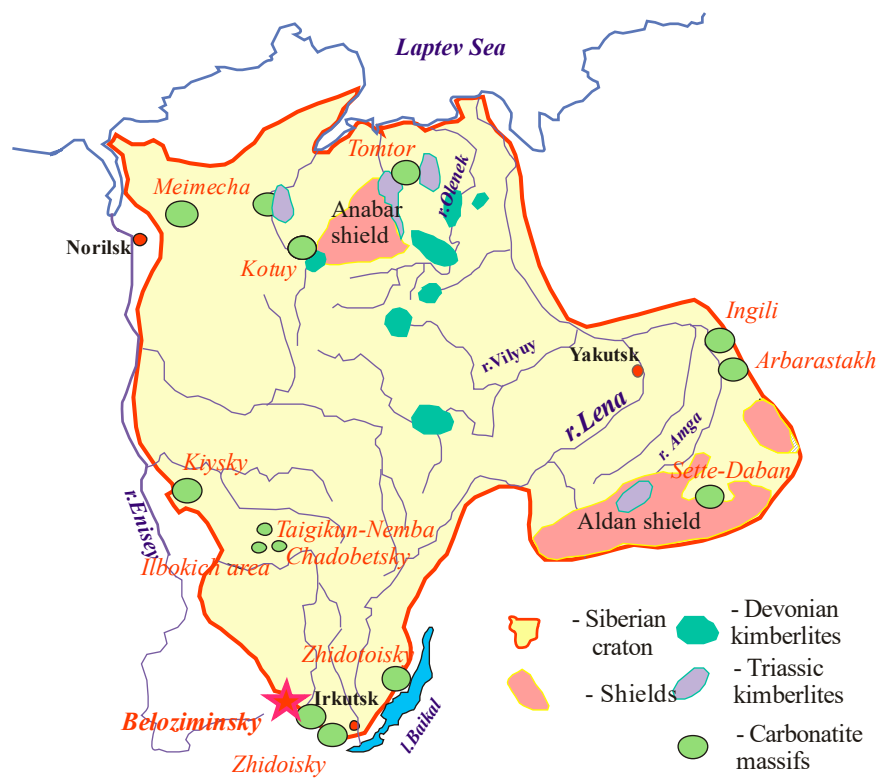

Figure 1. Location of the carbonatitic complexes on the Siberian craton.

Aillikites often carry mantle xenocrysts and xenoliths especially those associated with the kimberlites [29] but detailed studies of these mantle rocks with isotopic compositions and trace element distributions were not yet published. The special explorations devoted to the differences of the aillikites that accompanied the kimberlites and carbonatite massifs were also not yet published, and the influence of the geodynamic settings on the mineralogy and rock compositions was not yet determined.

The relationships of carbonatite-ultramafic complexes with subduction [1,2,14], mantle convection and plume events [1,2,20-29,31,32] have been widely discussed. However, the nature of ore concentrations in the mantle level is not clear. Most authors agree that they are associated with mantle metasomatism related to modern or ancient subduction [1-29,31,32].

In Siberia, aillikites were discovered in the Chadobets uplift [30] and in the Tomtor carbonatite massif [33]. We also checked the series of alkaline lamprophyres rocks in dykes and necks in and near the Beloziminsky massif (BZM) [34-46] in the foothills of the Eastern Sayan mountains and found that they are typical aillikites, but were previously described by alnöites [34-37] and melilitites [42]. 
The great difference of the BZM series of aillikite is their high enrichment in trace elements and different ore components determined by their close relationships with the carbonatites, which are the main sources of REE, and contain essential amounts of rare metals $(\mathrm{Ta}, \mathrm{Nb})$ and others, chalcophile $(\mathrm{Pb}, \mathrm{Cu}, \mathrm{Zn}$, etc.) and siderophile elements (Fe, Mn) [34-46].

This study is only a brief description of results obtained in IGM Novosibirsk for 50 BZM aillikite samples. In this paper we gave only general outlook of the problems connected with the lamprophyres of the massif. The detailed mineralogical database of $>1200$ mineral analyses obtained with the electronic microprobe and microscopes and new, more detailed mineralogy will be described in other publications as well as the detailed division into petrographic and genetic groups. A new database has about 50 more bulk rock ICP MS analyses and isotopic investigations is in preparation.

\section{Geological Situation}

There are several carbonatite ultramafic complexes in the marginal zones of the Siberian craton [6,21,25,33,47-52] (Figure 1) One of the interesting objects with the complex plume-subduction nature is the Beloziminsky massif (BZM) [34-46] which has various metallogenic specialization in Ta, $\mathrm{Nb}, \mathrm{REE}$ and $\mathrm{P}$, and a wide range of components including Th and $\mathrm{U}$. It was involved in exploration despite its distant location $(140 \mathrm{~km})$ from the railway. Concentrate of ore minerals was obtained from the excavated weathering crust in an open pit in the 1990s. The main source of these elements are carbonatites and ijolites of late ankerite carbonatite phases. There are four main types of ores: (1) polymetallic galena-sphalerite-chalcopyrite; (2) parisite-bastnäsite-monazite; (3) apatite-magnetite-pyrochlore; and (4) apatite-pyrochlore-columbite [35-38]. In the quarry, deposits of Ta-bearing Ti-magnetites with other high field strength elements (HFSE) with Mn were explored.

Formation of the massif, like many other similar alkaline and carbonatitic massifs on the boundary of the Siberian continent, are associated with the global Angara-Taimyr rift structure [27,46], formed during the last stages of the supercontinent Rodinia breakup [46,48-52]. Paleo reconstructions for Siberia show that BZM massif is associated with the Srednezimisky and Bolshetagninsky massifs (Figure 2) [10].

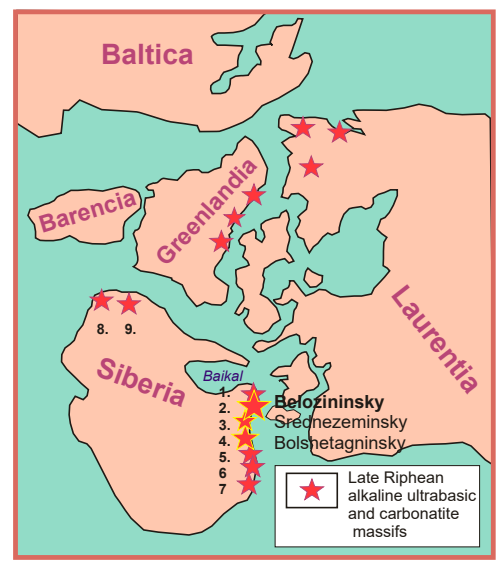

Figure 2. Paleo reconstruction for the Vendian (Neoproterozoic III) time of the Northern continents [16-19]. Carbonatite massifs: 1-Zhidoysky; 2-Beloziminsky; 3-Sredneziminsky; 4-Bolshetagninsky; 5-Arbarastakh; 6-Srednetatarsky; 7-Tatarsky; 8-Ingili; 9-Kiysky (redrawn from [10] with the additions).

The massifs are located in East Sayan foothill within the Urik-Iya graben intruding Lower Proterozoic terrigenous rock series (Figure 3) [35]. The BZM massif consists of ijolite-melteigite, carbonatite rock series and ultramafic lamprophyre (aillikite) intrusions [35,44] (Figure 4). The late-stage carbonatite rocks are dolomite, calcite and final ankerite carbonatite varieties.

Ultramafic rocks (dykes and stocks) with abundant phlogopite, carbonates, Ti-magnetite and rarer pyroxene, olivine and amphibole are found in two positions. The relics of the early bodies are 
located at the NE core part of the massif [35,36]. The first one is represented by mafic variety described as melilitite, alnöites or nephelinite [34-44], but melilite occurs rarely in this rock series, which are characterized by fine or cryptic groundmass structure (Figure 5a). The second group are the youngest diopside-phlogopite dykes emplaced near the border and becoming more common in prevailing NNE direction of Proterozoic terrigenous strata. They contain a lot of serpentinite xenoliths with Cr-spinels and abundant sulfide.

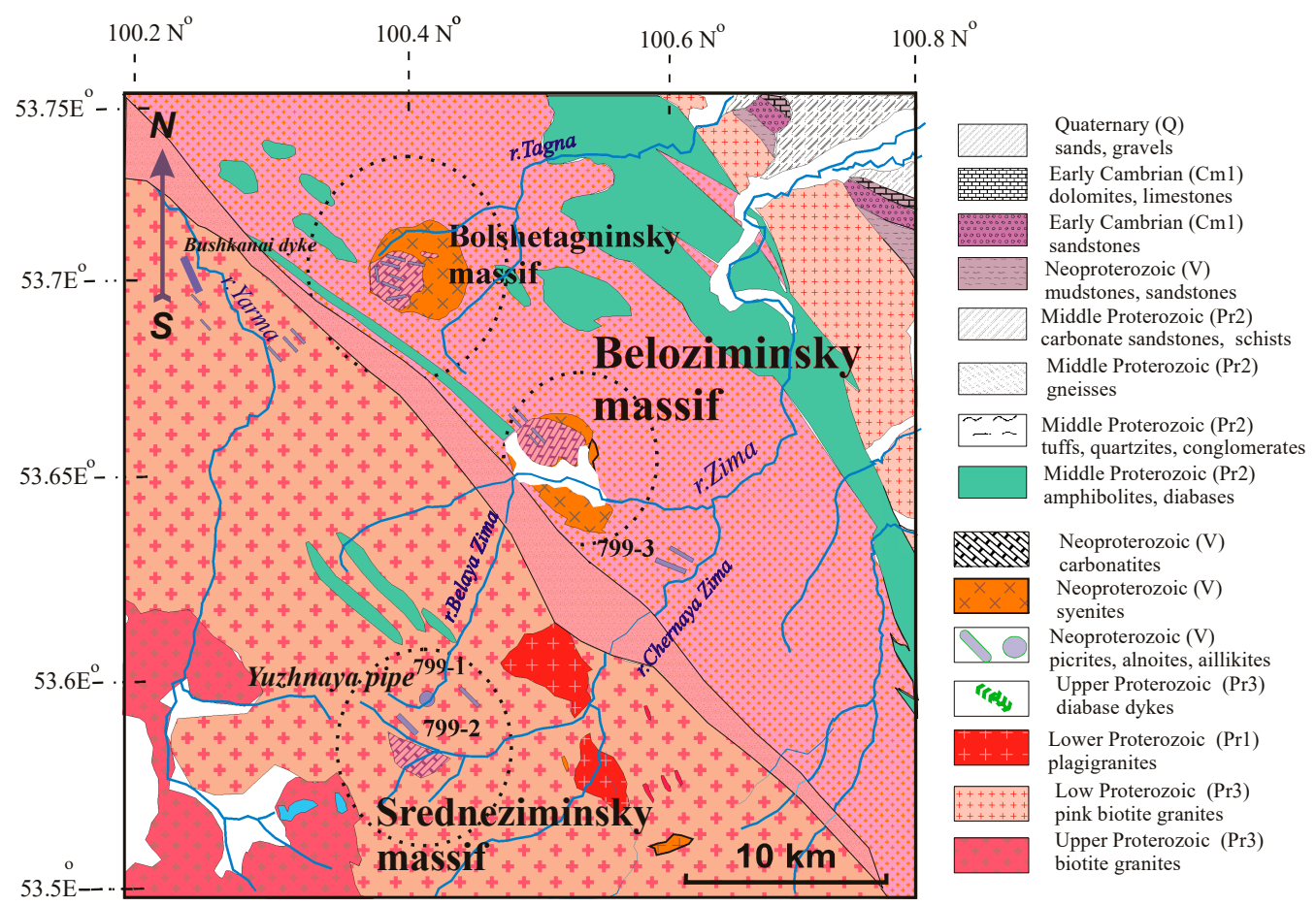

Figure 3. Geological scheme of the Nizhnesayansky alkali ultramafic carbonatite complex including Beloziminsky, Sredneziminsky; Bolshetagninsky massifs (redrawn from [35]).

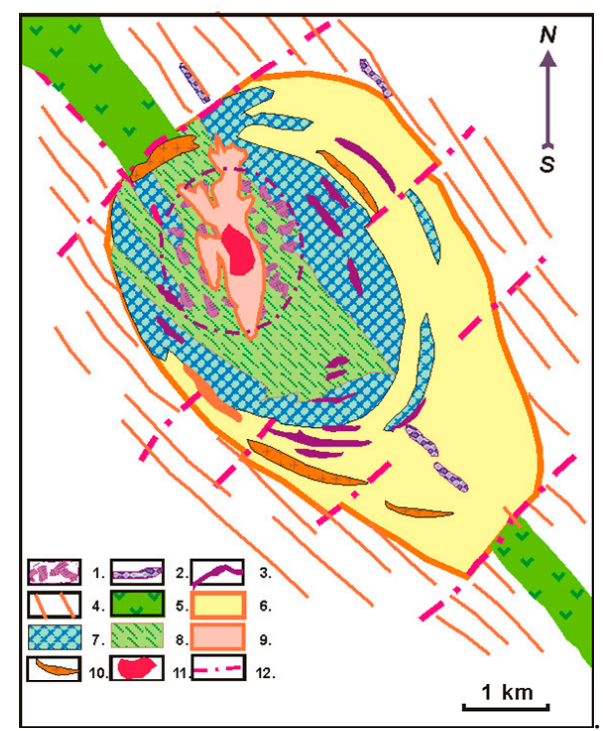

Figure 4. Geological scheme of Beloziminsky massif: (from [35]). 1—early aillikites (alnöites), 2-late aillikite dykes, 3-Phl-forsterite-diopside carbonatites (aillikites), 4-Middle Proterozoic schists, 5-Middle Proterozoic amphibolites, 6-melteigite-ijolites, 7-calcite carbonatites; 8-calcite-dolomite carbonatites, 8-amphibole-calcite carbonatites, 9-ankerite carbonatites; 10 -nepheline (Ne) syenites; 11-parisite-bastnäsite-monazite ores, 12 -faults. 

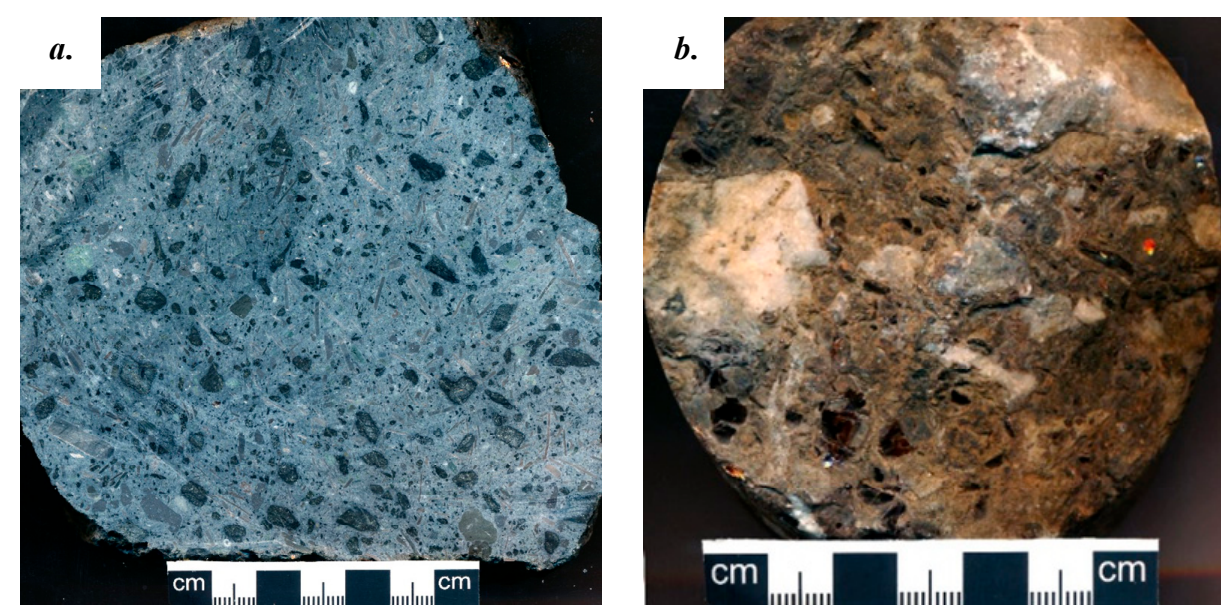

Figure 5. Scanned image of the cut sample from YuP (a). Photo of the of Phl aillikite breccia (b) with xenoliths of carbonatites.

A series of olivine, diopside, phlogopite-bearing essentially carbonatitic rocks with giant grained phlogopites and xenoliths of carbonatites (Figure $5 b$ ) form the lenses concordant with the concentric fracturing within the massif cutting the carbonatites. In our opinion, also corresponding to ultramafic lamprophyres and according to $\mathrm{SiO}_{2}-\mathrm{CO}_{2}$ contents, they are close to aillikites compared with the average compositions of these rocks [1]. These magmatic breccias contain fragments of carbonatites sometimes with ore minerals (Figure $5 \mathrm{~b}$ ). Fresh grains of olivines, $\mathrm{Cr}$-spinels, ilmenites and grossular or almandine garnets also are common.

Upstream in the Belaya Zima river $15 \mathrm{~km} \mathrm{SW}$ of BZM there is a neck of lamprophyric breccia called the Yuzhnaya pipe (YuP) with Mg' (Mg number) 0.7 (sample 799-1) containing xenocrysts of Cr-diopside, Ti-augites, olivines, amphiboles (kaersutite, pargasite), and xenoliths of serpentinized Spl-bearing dunites [52] with sulfides and $\mathrm{Cr}$-spinels (20-25\% $\mathrm{Cr}_{2} \mathrm{O}_{3}$ ). These rocks of $\mathrm{YuP}$ were considered to be melilitites or alnöites [52] but in all diagrams, they are closer to aillikites than alnöites (see Figures 9 and 10).

At a distance of $\sim 1 \mathrm{~km}$ upstream from the YuP, a substantially carbonatite dyke is exposed containing monticellite, pyroxenes and mica xenocrysts (sample 799-2), with debris of glimmerites and carbonatites containing fluorite. Another ultramafic dyke near the mouth of the Chernaya Zima river contains xenocrysts of augite (3-9 $\mathrm{wt} \% \mathrm{Al}_{2} \mathrm{O}_{3}$ ), amphibole, chromite, mica and rarer olivine $\left(\mathrm{Mg}^{\prime} \sim 0.84-0.88\right)$. One more large Bushkanai aillikitic (alnöitic) dyke [53] is situated $9 \mathrm{~km}$ west of BZM contain Cr- diopsides and olivines (Figure 3).

\section{Samples}

We collected samples of the Yuzhnaya pipe from large blocks exposed near the pipes and the other dykes outcropping in the riverbanks. We sampled material of one of the drilling stores containing only ultramafic lamprophyres from the BZM near the Belaya Zima settlement. Collected 270 samples were at first divided into several groups according to the petrographic and mineralogical compositions and studied by analytic methods. The major first group include the samples which are close to the YuP in texture (Figure 5a; Figure 6a,b) and contain macroscopic dark inclusions of the serpentine (altered ultramafic xenoliths) and Cr-diopsides, they also occur more rarely in the massif. Another group composed of the several varieties have similar cryptic groundmass structure and porphyroclasts of amphiboles and clinopyroxenes. The third large group includes rocks with pegmatoid structures and giant-grained phlogopites (Figure 5b). 

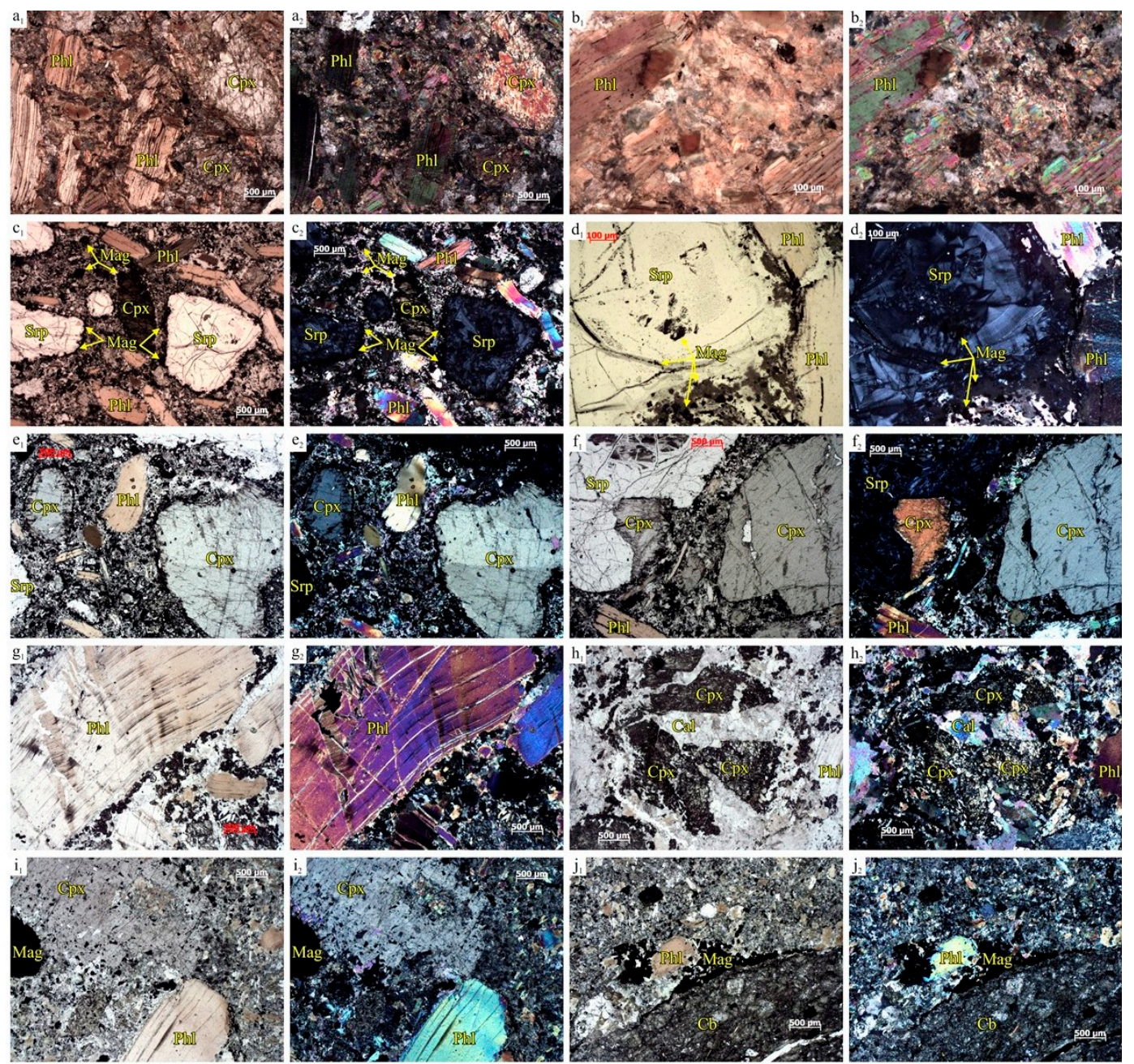

Figure 6. Photos of the aillikites in thin sections ( ${ }_{1}$-parallel and ${ }_{2}$ - crossed nicols) of samples BZ726 (a,b), 799-1 (c-f), BZ732 (g,h), BZ742 (i,j). (a) The aillikite has a porphyritic, lamprophyre structure. The pyroxene grains (Cpx) are deformed, with wavy extinction of phlogopite (Phl) grains, among the fine-grained serpentine-chlorite-carbonate-phlogopite groundmass with a thin rash of magnetite. (b) Phlogopite (Phl) phenocrysts are in the (carbonate Ca-chlorite-Cl-phlogopite) bulk of aillikite. (c) The aillikite has a porphyric structure. Pyroxene phenocryst $(\mathrm{CPx})$ and partially deformed phlogopite phenocrysts ( $\mathrm{Phl})$. Relatively large grains are olivines which are replaced by serpentine (Srp), with a thin rash of magnetite (Mag) inside the grains and in large quantities along the edges of the grains (grains encircled by magnetite). The bulk is carbonate, phlogopite, magnetite, chlorite (d). There is a fragment of olivine grain replaced by serpentine (Srp), in the marginal part of which magnetite (Mag) is widely developed. On the right are phlogopite (Phl) phenocrysts. (e) Phenocrysts of pyroxene (CPx) and phlogopite (Phl) among the carbonate-chlorite-phlogopite- magnetite mass. (f) There are phenocrysts of pyroxene (Cpx), phlogopite (Phl) with fragments olivine grains substituted by serpentine (Srp). The bulk is represented by chlorite, carbonate, phlogopite, magnetite. (g) Phenocrysts of phlogopite (Phl) with wavy extinction in the bulk consisting of carbonate, phlogopite, magnetite, epidote or millerite. (h) There are pyroxenes (Cpx) which are replaced by an epidote. In the center, between the grains of pyroxene is calcite (Cal). The bulk is carbonate, phlogopite, chlorite, magnetite. (i) Large phenocrysts of pyroxene (Px) (with a poikilitik structure) and phlogopite (Phl) in a fine-grained polymineral mass consisting of phlogopite, magnetite, carbonate, and chlorite. (j) There is a contact of aillikite with a carbonatite melt $(\mathrm{Cb})$. Along the boundary are clusters of magnetite (Mag). Photos of the aillikites in thin sections (crossed nicols). Fine grained aillikite with $\mathrm{Phl}(\mathbf{a}, \mathbf{b})$; fine grained aillikite with Phl, apatite rimmed by magnetite (c); twinned phlogopite grain with apatite inclusions. 


\section{Methods}

Mineral compositions were analyzed by the wavelength-dispersive analysis using an electron microscopes and Jeol Superprobe in Analytic Sobolev V.S. Institute of Geology and Mineralogy SB RAS, Novosibirsk, Russia (standard conditions) using $15 \mathrm{kV}$ acceleration voltage and $15 \mathrm{nA}$ beam current in epoxy mounts. Minerals and rocks were analyzed in thin sections according to the procedure of $[28,54]$. The relative standard deviation does not exceed $1.5 \%$; the precision was close to $0.02-0.01 \%$ for minor elements.

The detailed mineral composition of $\sim 800$ grains were studied using a MIRA 3 LMU scanning electron microscope with an attached INCA Energy 450 XMax 80 microanalysis energy-dispersive system (SEM-EDS) at the X-ray Laboratory of the Institute of Geology and Mineralogy, Siberian Branch, Russian Academy of Sciences (analysts Ashchepkov I.V., Karmanov N.S., Belyanin D.S.)

The bulk rock compositions were measured by X-ray fluorescence method (XRF) using BRA-135F apparatus in glasses prepared for XRF by the melting of rock powder with Li-tetraborate.

More than 80 mineral grains from 15 aillikite samples were analyzed by laser ablation in Nikolaev's IIC SB RAS using the mass spectrometer aniCAP Q (Thermo Scientific) with the Nd UV laser NWR 213 (New Wave Research) (analyst N.S. Medvedev). As standards the NIST 610-612 SRF were used. We used for the secondary standard garnets and clinopyroxenes sample 313-73 analyzed by solution ICP MS in MRAC Belgium [55]. The method has a detection limit $\sim 10^{-7}(0.1 \mathrm{ppm})$ and standard deviation of the measurements for most isotopes was about $7-15 \%$.

The trace elements of bulk rock compositions of 12 samples were analyzed twice, at first in glasses by laser ablation ICP MS using the method described above, and then they were analyzed in solution under standard conditions with a Thermo Finnigan Element 2 single-collector at low (LR)-300, medium (MR)-4000, and high (HR)-10000 M/ $\Delta \mathrm{M}$ resolution. The measurement results and instrumental drift were checked against international standards BHVO-1, STM-1. The glasses obtained by fusion with $\mathrm{LiBO} 2$ were dissolved in ultra-pure $\mathrm{HNO}_{3}$ to prepare sample solutions

The age of aillikites estimated by ${ }^{40} \mathrm{Ar} /{ }^{39} \mathrm{Ar}$ age using the method was described in detail by Travin et al. [56]. Quartz ampoules with samples were irradiated in the Cd-coated channel of a reactor (BBP-K type) at the Tomsk Polytechnic Institute. The gradient of the neutron flux did not exceed 0.5\% of the sample size. Step-heating experiments were carried out in a quartz reactor with an external heater. The blank for ${ }^{40} \operatorname{Ar}\left(10 \mathrm{~min}\right.$ at $\left.1200^{\circ} \mathrm{C}\right)$ was not higher than $5 \times 10^{-10} \mathrm{~cm}^{3}$. Ar was purified using $\mathrm{Ti}$ and $\mathrm{ZrAl}$ SAES getters. The isotopic composition of Ar was measured on a Micromass Noble Gas 5400 mass spectrometer (analysts Travin A.V., Yudin D.S.).

\section{Age}

Dated by the ${ }^{40} \mathrm{Ar} /{ }^{39} \mathrm{Ar}$ method, aillikite and ultramafic bodies display a range of ages from 645 to $622 \mathrm{Ma}$ (Figures 7 and 8, Table S1). The Yuzhnaya pipe [43] has been dated at $645 \mathrm{Ma}$ (Figure 7) which coincides with the age of the carbonatites from the other massifs in South Eastern and Western Siberia massifs $[4,46,50]$. A regression through barely distributed points of YuP with very low ${ }^{39} \mathrm{Ar} /{ }^{40} \mathrm{Ar}$ values provides an age of $666 \pm 18 \mathrm{Ma}$ (Figure 7) Yet, this 'isochron' is of doubtful geological significance in view of the $204 \pm 20$ value of ${ }^{36} \mathrm{Ar} /{ }^{40} \mathrm{Ar}$ that suggests there might be partial loss of radionic $40 \mathrm{Ar}^{*}$. At any rate, such an age of ca. 666 for the YuP could refer to the separation of a local melted zone within the mantle which gave the melt for the YuP. The early phase YuP was dated by $\mathrm{Rb} / \mathrm{Sr}$ isochron as Early Proterozoic [42]. Our ${ }^{40} \mathrm{Ar} /{ }^{39} \mathrm{Ar}$ age of $\mathrm{YuP}$ at ca. $645 \mathrm{Ma}$ is slightly older than age of the carbonatites of the BZM massif (640-645 Ma) [38,39]. All analytic data are given in the supplementary data files.

Aillikite breccias in BZM represent by essentially phlogopite-bearing varieties with abundant carbonatites yielded reveal ages ranging from ca. 622 Ma to 640 Ma divided in three intervals 621-627, 630-633 and $640 \mathrm{Ma}$ (Figures 7 and 8) with a tendency of increasing carbonatite component in younger rocks. Carbonate-rich aillikitic dykes located at 10-15 km distance from BZM appears to be younger as inferred from the plateau age of ca. $584 \mathrm{Ma}$ (total gas age $595 \mathrm{Ma}$, Figure 7). 

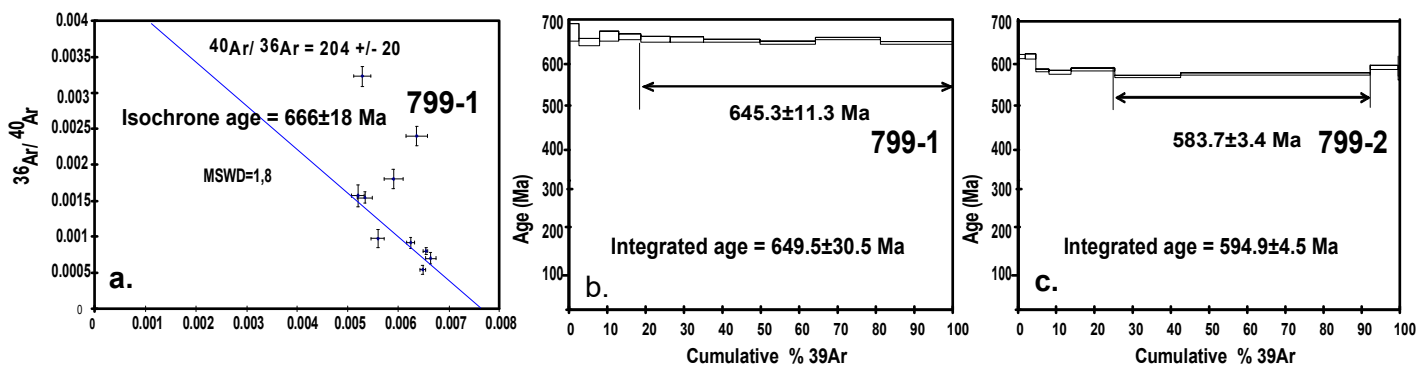

Figure 7. Results for the ${ }^{40} \mathrm{Ar} /{ }^{39} \mathrm{Ar}$ dating of $\mathrm{YuP}(\mathbf{a}, \mathbf{b})$ and carbonatite phlogopite-bearing dyke (c) located nearby.

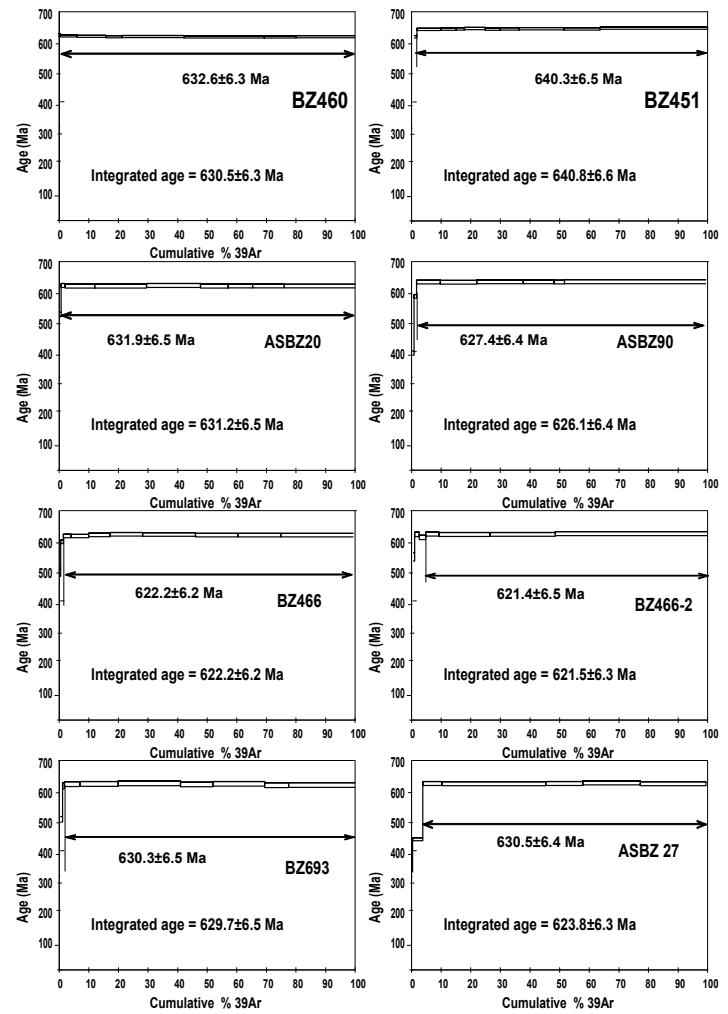

Figure 8. Results for the ${ }^{40} \mathrm{Ar} /{ }^{39} \mathrm{Ar}$ dating of lamprophyre dykes and stocks inside the BZM.

\section{Whole-Rock Compositions}

\subsection{Major Element Compositions}

The series of the ultramafic alkaline carbonatite complexes in Central Asia [33-44,47-52] and worldwide [1-22,26-29] often contain lamprophyres sometimes close to aillikites [1,2].

Rock compositions of studied lamprophyres vary greatly from $14 \mathrm{wt} \% \mathrm{SiO}_{2}$ from Phl carbonatite to $42 \mathrm{wt} \% \mathrm{SiO}_{2}$ (close to ijolites) (Figure 9, Table S2). The variations of $\mathrm{SiO}_{2}$ and major elements are similar to aillikites of Labrador [7,13,57] and other regions such as the Tomtor massif $[6,47,58,59]$, Chadobets uplift [31,33], Scotland [23], Greenland [20,27] and Eastern India [28]. The average aillikite composition from 232 samples worldwide [1] practically coincides with the composition of some aillikites from BZM but many of the latter are richer in alkalis and $\mathrm{Al}_{2} \mathrm{O}_{3}$ (higher modal proportion of $\mathrm{Phl}$. The BZM aillikites are enriched in alkalis and alumina but depleted in $\mathrm{TiO}_{2}$ compared to Labrador aillikites $[7,13,29,57]$. 


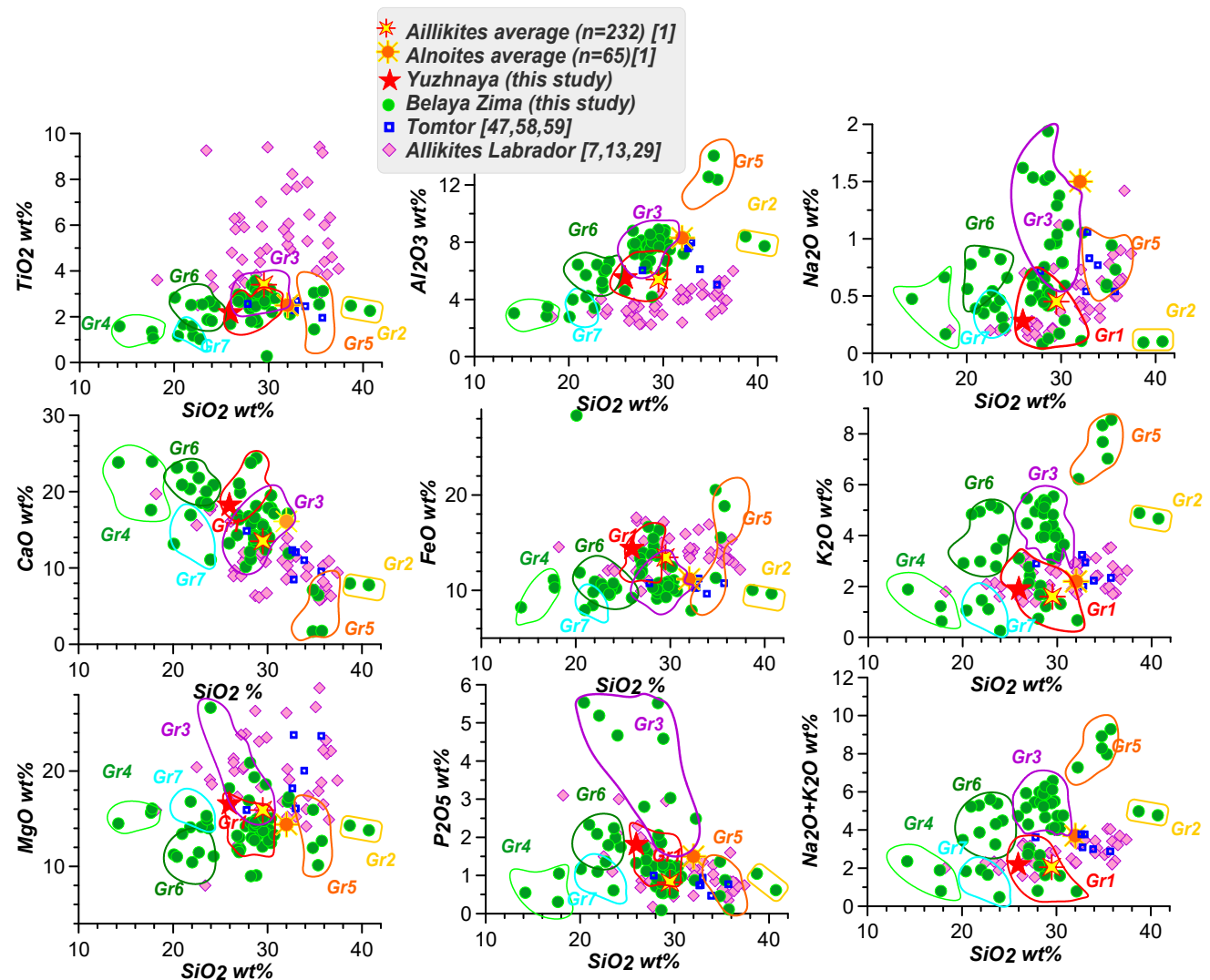

Figure 9. Variations of bulk rock compositions of BZM aillikites in comparison with the Labrador aillikites $[7,13,29,57]$ and Tomtor lamprophyres $[6,47,58,59]$.

We divided the studied collection into 7 groups according mainly to their bulk rock compositions accounting the trace element compositions, supported by the mineralogy. The first group is represented by composition of the YuP and two close compositions from BZM with Mg\# $\sim 70 \pm 5$ and relatively low alkalis with some dominance of $\mathrm{K}_{2} \mathrm{O}$. The rocks of the second group are rare. They are the most $\mathrm{SiO}_{2}$-rich samples with low $\mathrm{CaO}$ content and as well most of other components. The contents of $\mathrm{K}_{2} \mathrm{O} \sim 6$ $\mathrm{wt} \%$ and $\sim 40 \mathrm{wt} \% \mathrm{SiO}_{2}$ attesting that these are practically monomineralic phlogopite rocks. The third group is very similar to the first group and differs mainly in the higher content of alkalis both $\mathrm{K}_{2} \mathrm{O}$ and sometimes extremely high $\mathrm{Na}_{2} \mathrm{O}$. These features suggest that they are aillikites rich in mica and alkali pyroxenes. The fourth group is the early emplaced carbonatitic group with $12-15 \mathrm{wt} \% \mathrm{SiO}_{2}$. It is lower in all oxides except for $\mathrm{CaO}$ and $\mathrm{MgO}$. Group 5 is enriched in $\mathrm{Al}_{2} \mathrm{O}_{3}, \mathrm{FeO}$ and alkalis due to the abundance of magnetite and Ti-biotites. Groups 6 and 7 have similar silica content $20-25 \mathrm{wt} \%$ and differ mainly in the abundance of $\mathrm{P}$ and $\mathrm{Na}_{2} \mathrm{O}, \mathrm{K}_{2} \mathrm{O}$ determined by mica, pyroxenes and apatite within the rocks. The sixth group is more enriched in alkalis, alumina and $\mathrm{TiO}_{2}$.

The groups determined on the diagram only partly coincide with the clots of concentrations of components vs $\mathrm{Mg \#}$ (Figure 10). The reasons are described in discussion. In the diagram of $\mathrm{Mg}^{\prime}$ vs major components, the trends look smoother. We consider that the primary melts are the varieties between $\mathrm{Mg}^{\prime} 0.63$ and 0.79 because they correspond to the equilibrium with the dominant values of mantle olivines $\left(\mathrm{Mg}^{\prime}=0.9\right.$ and 0.93$)$ (Figure 10). We calculated the equilibrated olivine compositions using a partition coefficient (KD) of olivine-melt close to 0.33 [60]. According to this division, almost all BZM lamprophyres are located within the primary melts field or from the metasomatized mantle spreading commonly to 0.84 in $\mathrm{Mg}^{\prime} \mathrm{Ol}$ (or 0.57 for the parental melts).

The variations of the bulk rock compositions in time (Figure 11) show the vast variations. The major tendency is general degrease of the $\mathrm{MgO}$ and increase of $\mathrm{CaO}, \mathrm{TiO}_{2}$, alkalies (carbonatite component) in time. 


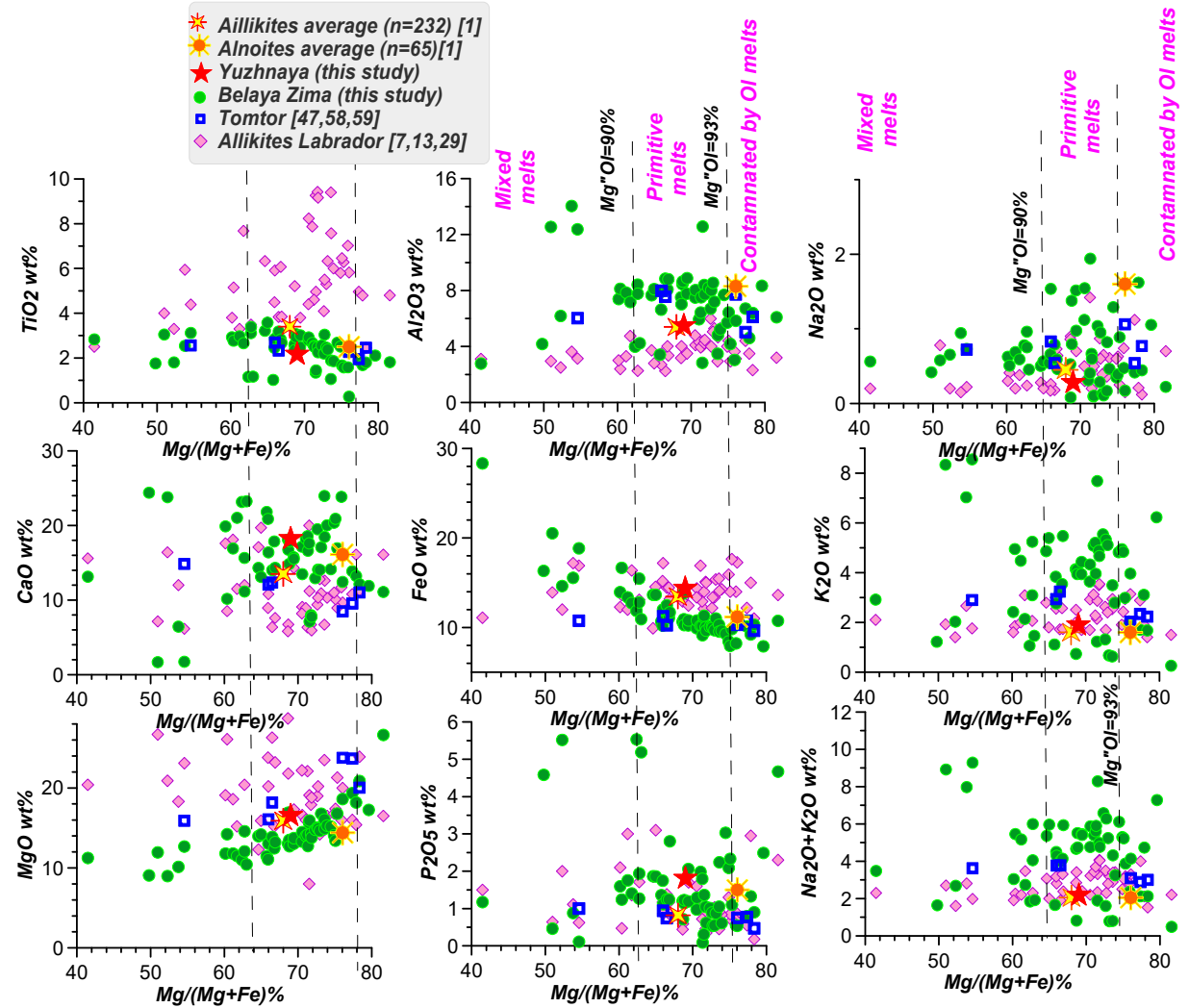

Figure 10. Variations of the major components versus $\mathrm{Mg}^{\prime}$ for $\mathrm{BZM}$ aillikites, see explanation in the text.
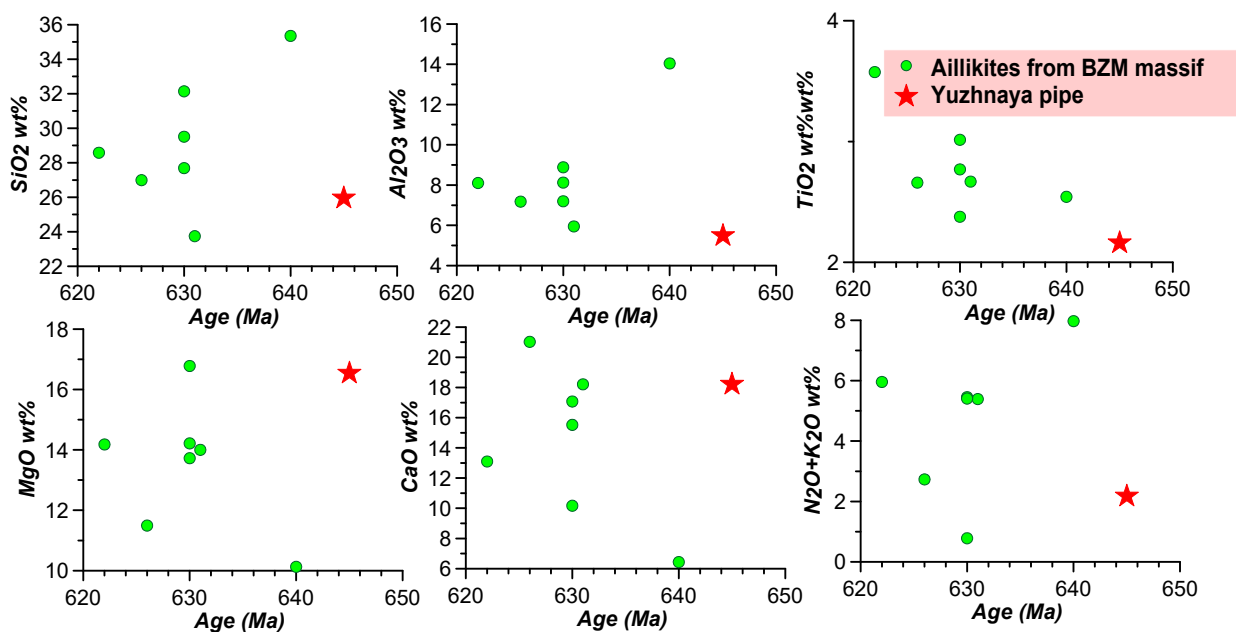

Figure 11. Variation of chemical composition with ${ }^{40} \mathrm{Ar} /{ }^{39} \mathrm{Ar}$ age for BZM aillikites.

\subsection{Rare Elements for Bulk Rock Composition}

All the REE patterns of bulk rock compositions of aillikites (close to YuP) are inclined, with variations in $\mathrm{La} / \mathrm{Yb}_{\mathrm{n}}=7-12$. La varies from 200 to 500 relative to the primitive mantle (PM) [61] (Figure 12, Table S2). We divided the trace element patterns of studied aillikites into 7 groups which are supported by the bulk rock grouping.

The first group of the most primitive patterns of aillikites corresponds to the typical spectra of low degree melting of primitive mantle [61]. In particular, the REE of YuP aillikite growth from $\mathrm{Yb}$ to La, and high large ion lithophile elements (LILE) are lower than for other rocks. The high field strength elements (HFSE) are not fractionated or have very weak minima in $\mathrm{Zr}, \mathrm{Hf}, \mathrm{Ta}, \mathrm{U}$ and are more 
pronounced in $\mathrm{Sr}, \mathrm{Pb}$. Very similar samples were found within the massif and as well in Buskanay dyke [53]. This group is suggested to be primary melts (Group 1). The second group (second panel) with the flat hump at Gd-Pr-along the bent pattern is similar to clinopyroxene patterns from garnet-bearing mantle peridotites [55,62], with peaks in $\mathrm{Nb}$, Th, but low Hf. In the third group, some REE patterns of carbonatites have sharply increased La-1000-2000/C1 and HFSE ( $\mathrm{Nb}>>\mathrm{Ta}$ ); and lower $\mathrm{Zr}$ and Hf ( $\mathrm{Zr}>>\mathrm{Hf})$. The fourth group of rocks have sharply inclined and highly enriched REE patterns with LREE 10000/C1 and peaks of Th and Nb, but relatively lower LILE. The fifth group have intermediate enrichment in La-500-80/C1 but high $\mathrm{Nb}$ and $\mathrm{Ba}, \mathrm{Th}, \mathrm{U}$ and varying $\mathrm{Hf}, \mathrm{Ta}, \mathrm{U}$. The sixth group are phlogopite-enriched rocks with the lowest REE (La-50/C1) with flattened HREE patterns and enrichment of $\mathrm{Rb}, \mathrm{Cs}, \mathrm{Zr}, \mathrm{Ta}, \mathrm{Nb}$, and lower Th- $\mathrm{U}$. The seventh group are similar carbonatites but lower in phlogopites. They contain $\mathrm{Nb}, \mathrm{Na}, \mathrm{Zr}$ mainly as the inclusions of Ta- niobates and $\mathrm{Zr}-\mathrm{Na}$, Ta oxides (Figure 12).

This grouping is supported by the measurements of the radiometry for these rocks regulated by the abundance of $U$ and Th and proved by the more presentative study of $>50$ TRE bulk rock compositions (Zhmodik et al., in preparation). The reasons of the variations are described in discussion.
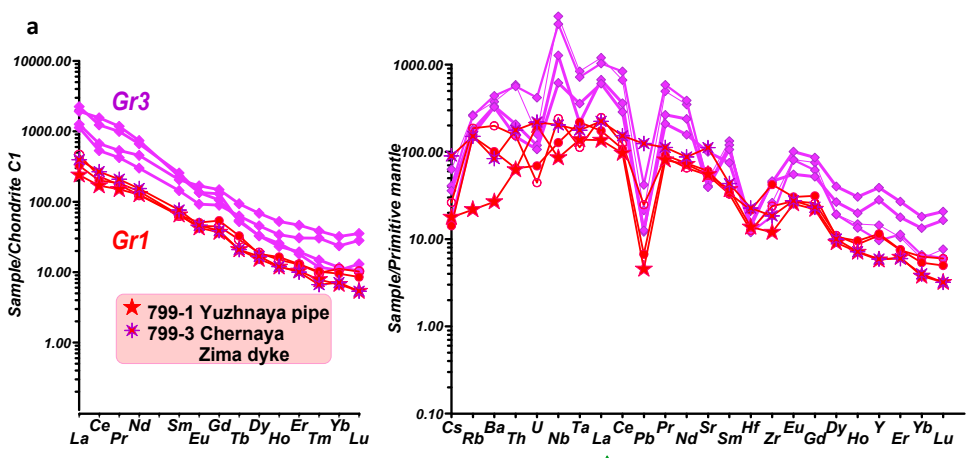

b
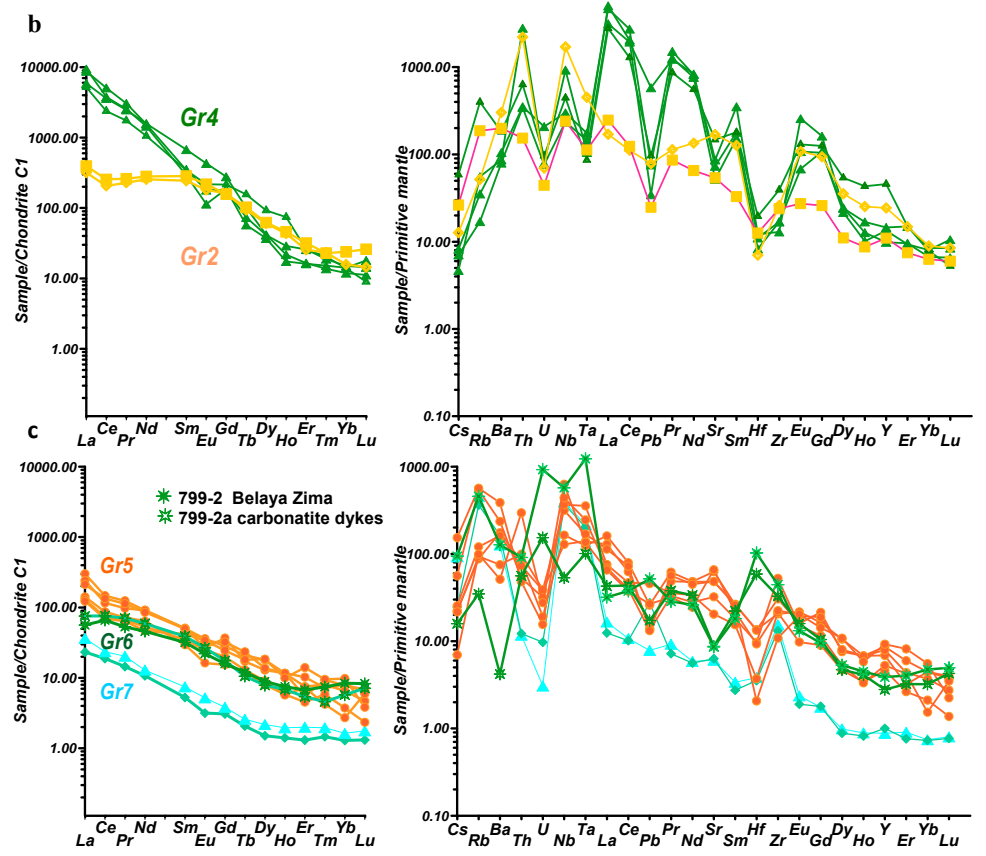

Figure 12. REE and TRE spectra of bulk composition of aillikites and carbonatites from BZM. Aillikites outside massif (a), aillkites in BZM (b), Phl carbonatities and aillikites (c). Normalized to primitive mantle [62] and chondrite $\mathrm{C} 1$. 


\section{Compositions of the Minerals}

\subsection{Variations of Major Elements in Minerals}

We mainly studied the mineralogy of the primary rocks such YuP and similar rocks in BZM but mineral compositions from other groups were also included (Table S3).

The pyroxene quadrilateral (Figure 13) [63] shows that all minerals have very wide compositional ranges formed at conditions from 1200 to $600{ }^{\circ} \mathrm{C}$ and less.

Clinopyroxenes ( $\mathrm{Cpx}$ ) from $\mathrm{YuP}$ were divided into 3 groups. Cpx from the most representative group 1 (Gr1) forms a trend from 5 to $12 \mathrm{wt} \% \mathrm{FeO}$ with a joint increase in $\mathrm{FeO}, \mathrm{TiO}_{2}, \mathrm{Al}_{2} \mathrm{O}_{3}, \mathrm{Na}_{2} \mathrm{O}$ and a decrease in $\mathrm{CaO}, \mathrm{MgO}$. Group $2 \mathrm{Cr}$-diopsides with the lowest $\mathrm{FeO}(\sim 3-4$ wt $\%)$ and $\mathrm{Cr}_{2} \mathrm{O}_{3}$ content (0.2-2 wt\%) and widely varying $\mathrm{Na}_{2} \mathrm{O}$ and $\mathrm{Al}_{2} \mathrm{O}_{3}$ are similar to the xenogenic mantle material (peridotite metasomatites in subduction-related settings) [64] and most lower in $\mathrm{Al}_{2} \mathrm{O}_{3} \mathrm{Cr}$-diopsides are close to dunites in carbonatite-ultrabasic massifs [65] (Figure 14).

Close to YuP Cpx are Cr-diopsides from Bushkanai dyke, but more Fe-rich varieties are close to Gr1. The $3^{\text {rd }}$ group of alumina-enriched augites up to fassaites, with intermediate $\mathrm{Mg}^{\prime}$ and sharply varying $\mathrm{TiO}_{2}$ and $\mathrm{Al}_{2} \mathrm{O}_{3}$ and low $\mathrm{Na}_{2} \mathrm{O}$. Among the clinopyroxenes from the $\mathrm{BZM}, \mathrm{Cr}$-diopsides occur rarely and they are slightly more Fe-rich than in YuP (Figure 14).

All minerals from carbonatites and ijolites BZM in general are much more Fe-rich (not in the diagrams) [38,39].

The amphiboles of pargasite-kaersutite type $\left(\mathrm{Mg}^{\prime} \sim 0.56\right)$ are close in $\mathrm{Mg}^{\prime}$ with the most Fe-rich pyroxenes (Figure 13).

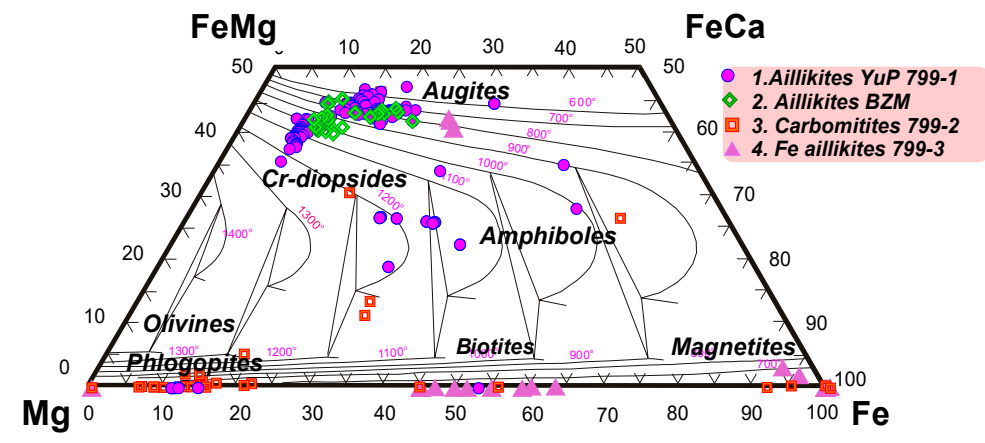

Figure 13. Pyroxene quadrilateral for aillikite minerals [63] of BZM, YuP and aillikites and carbonatite dykes located in Belaya Zima river basin. The compositions of olivines, amphiboles, phlogopites and magnetites are projected and do not corresponds the isotherms.

Phlogopites. We plotted together the compositions YuP and BZM with the addition of the minerals from Labrador aillikites [7,12,28,57]. According to Giuliani [66], different area in $\mathrm{FeO}-\mathrm{Al}_{2} \mathrm{O}_{3}$ and $\mathrm{TiO}_{2}-\mathrm{Al}_{2} \mathrm{O}_{3}$ may be attributes to aillikites, kimberlites, orangeites and lamproites. The phlogopites from YuP are essentially more Mg-rich and plot in the aillikite field tending to alnöites as well BZM phlogopites are more Fe rich and tends to alnöites. (Figure 15). Cr-phlogopites with 0.5-1.7 wt.\% $\mathrm{Cr}_{2} \mathrm{O}_{3}$ and $\mathrm{Mg}^{\prime}=0.88-0.85$ are probably in equilibrium with $\mathrm{Cr}$-diopsides, but the Ti-biotites with $\mathrm{Mg}^{\prime} \sim 0.55-0.54$ are in equilibrium with Fe-rich amphiboles (Figures 13 and 15).

The olivine compositions from the Yuzhnaya pipe and from BZM aillikite are quite variable. Those with $\mathrm{Mg}^{\prime}$ from 0.89 to 0.84 have very low $\mathrm{CaO}$ content. Two groups of olivines from the BZM show much higher $\mathrm{CaO}$ content to $0.4 \mathrm{wt} \%$, suggest $\mathrm{Ca}$-rich carbonatitic melts. Another group contains $\mathrm{MnO}$ to $4-6 \mathrm{wt} \%$, are found in aillikites enriched in carbonatitic material. Where ilmenites and magnetites contain $\mathrm{MnO}$ to $10 \mathrm{wt} \%$ (Figure 16).

Ilmenites from BZM plot in the $\mathrm{Fe}_{2} \mathrm{O}_{3}$-rich field. They are highly variable in $\mathrm{TiO}_{2}$. Some varieties are enriched in $\mathrm{Nb}_{2} \mathrm{O}_{5}$ to $9 \mathrm{wt} \%, \mathrm{~V}_{2} \mathrm{O}_{5}$ to $7 \mathrm{wt} \%$ and in $\mathrm{ZrO}_{2}$ to $1.3 \mathrm{wt} \%$ and have notable $\mathrm{Al}_{2} \mathrm{O}_{3}$ to $1.3 \mathrm{wt} \%$. 
There are essentially MnO-rich (to $30 \mathrm{wt}$ \% $\%$ varieties; the other group have 10 wt.\%. MnO (Figure 17). Mn-rich ilmenites are common in kimberlites [11].
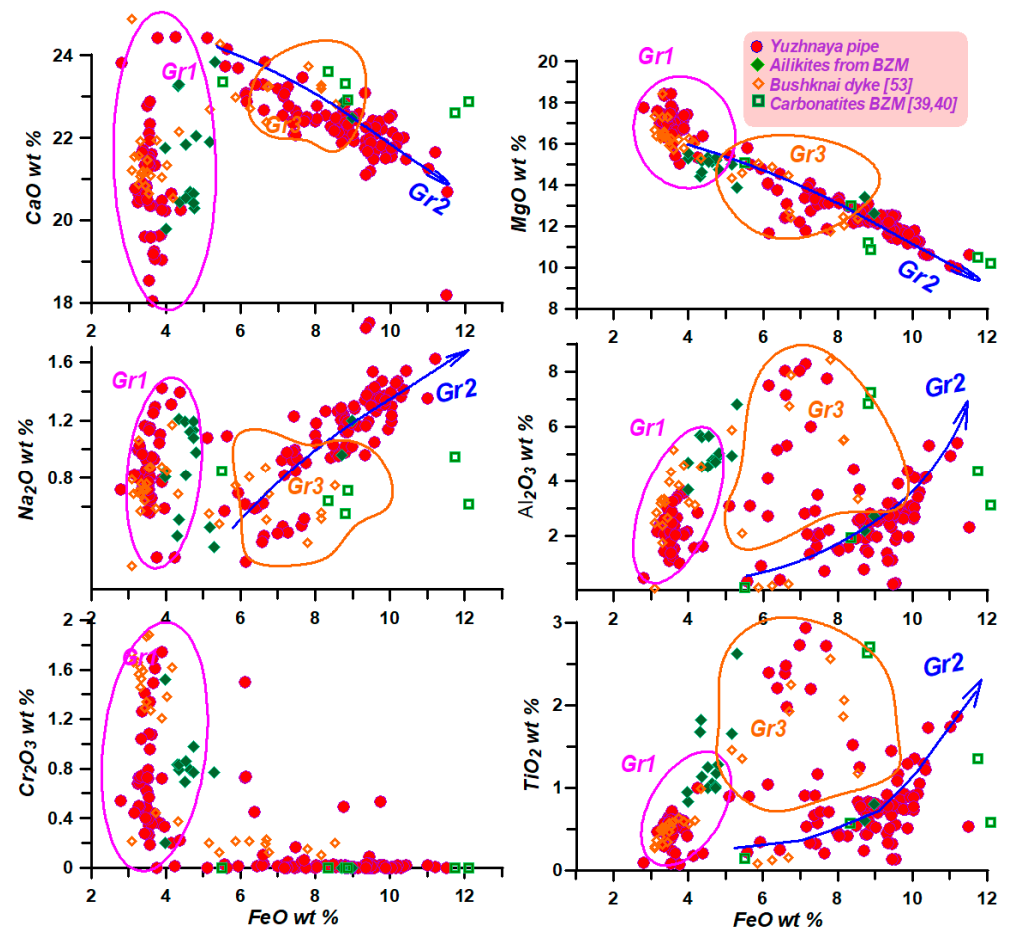

Figure 14. Variations of clinopyroxene compositions from aillikites of YuP, BZM and Bushkanai dyke [53].

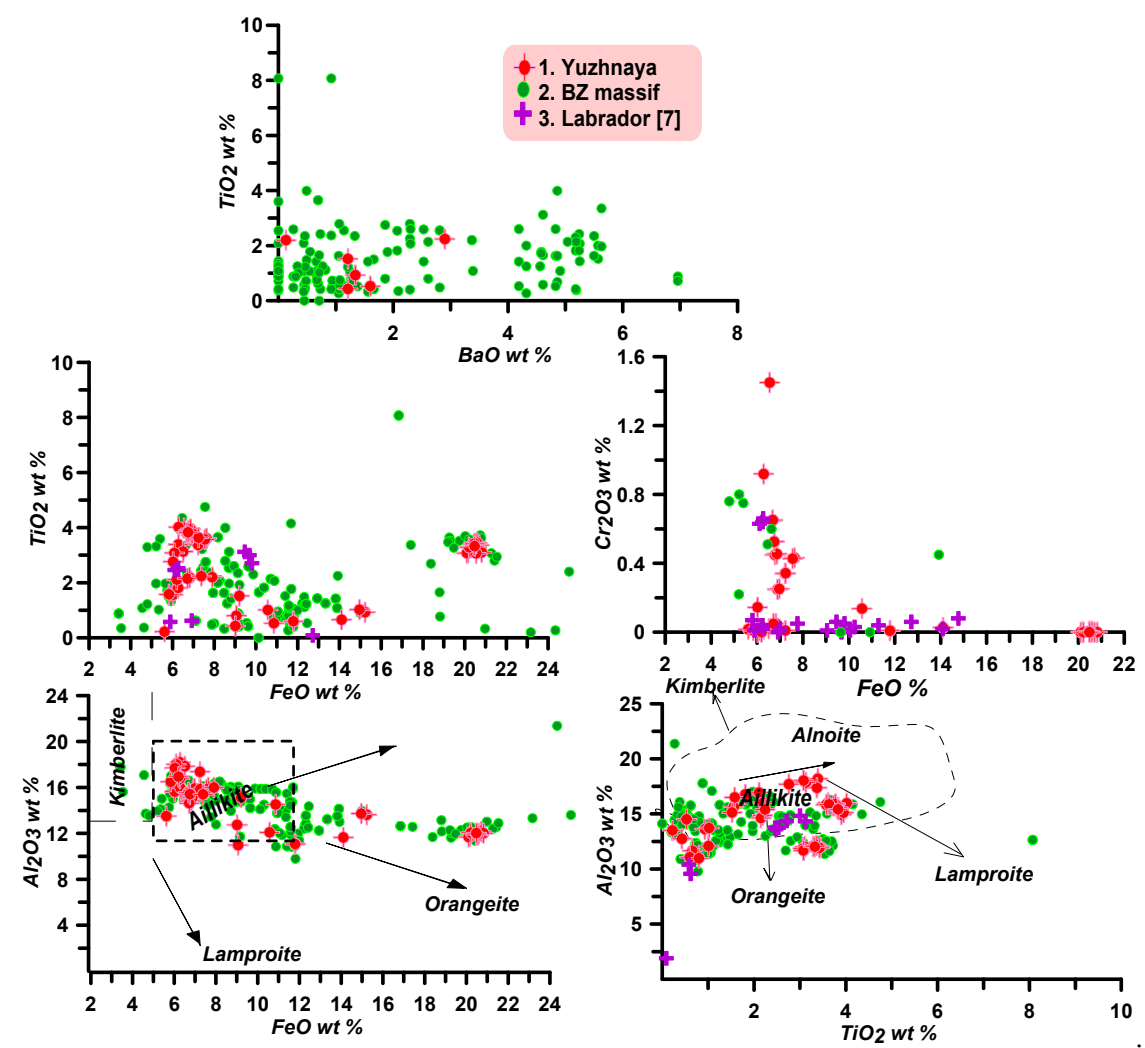

Figure 15. Variations of phlogopite compositions from BZM. The fields and arrows after [66]. 

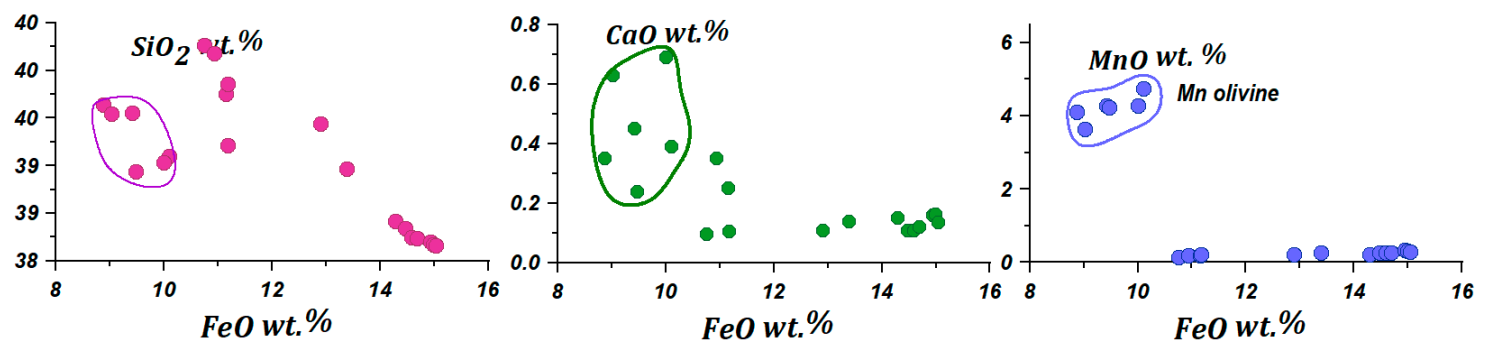

Figure 16. Variations of olivine compositions from BZM. The field of $\mathrm{MnO}$ is outlined.

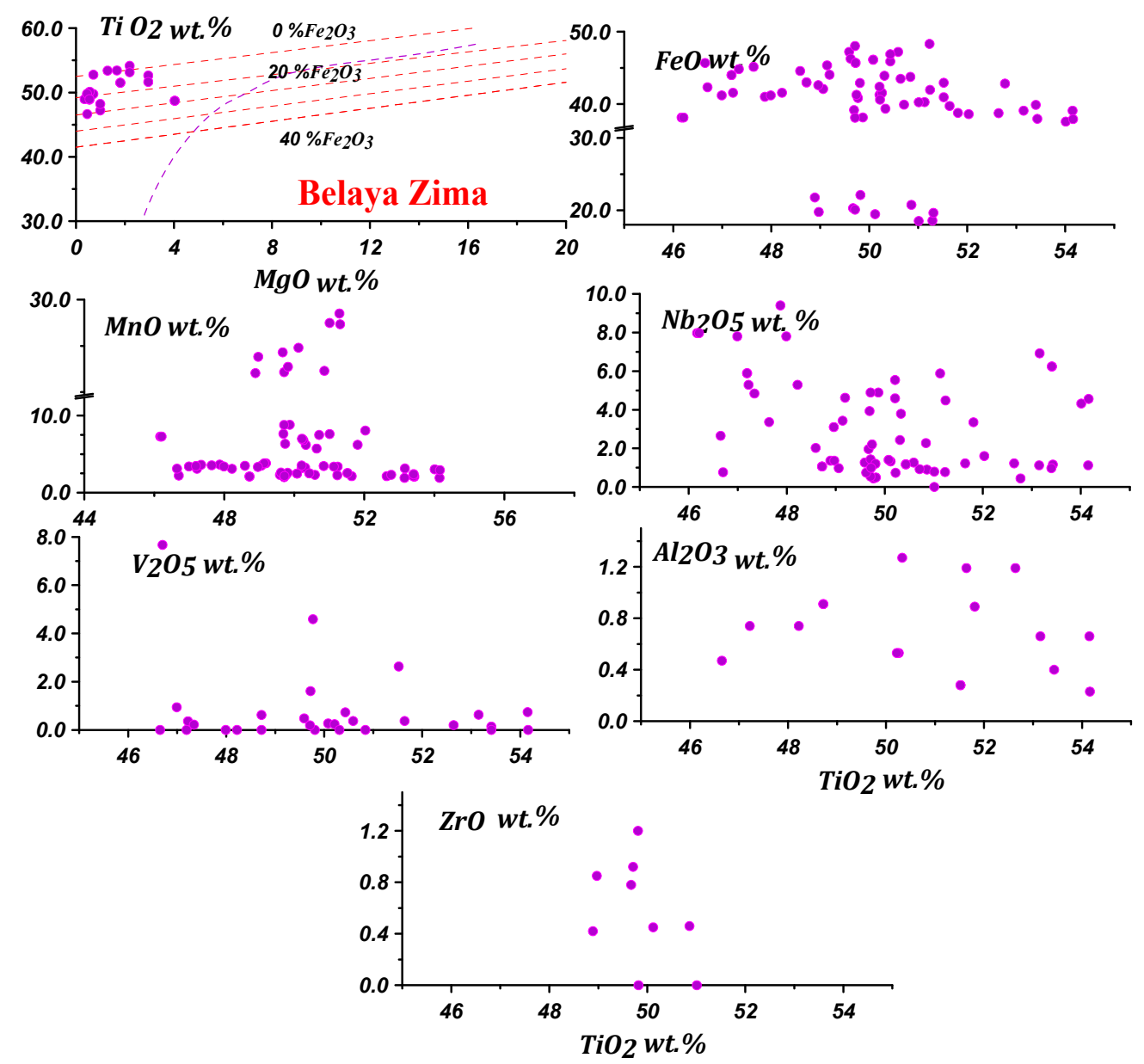

Figure 17. Variations of ilmenite compositions from BZM. The isopleth of $\mathrm{Fe}_{2} \mathrm{O}_{3}$ after [67].

\subsection{Rare Elements of Minerals from Yuzhnaya Pipe}

The patterns of rare elements in minerals from YuP were determined using grains selected from the heavy minerals separates (Table S4). Cr-diopsides (Gr1) have peaks of $\mathrm{Y}, \mathrm{Zr}$ and very high $\mathrm{Ba}$, $\mathrm{Th}, \mathrm{U}, \mathrm{Nb}$, Ta. Al- augites (Gr3) show highest REE level, inclined and slightly concave patterns with $\mathrm{La} / \mathrm{Yb}_{\mathrm{n}}>12-10$ and small Eu minima (Figure 18a).

Relatively low-Al augite-salite series show conformable and nearly straight REE patterns and very high Sr, Ba peaks and elevated HFSE. The concentrations of $U$, Th became lower more rapidly than REE (Figure 18b).

The REE patterns of Ti-biotites are very low (LREE 10/C1) and U-shaped. The Ta-Nb peaks are higher than the Zr-Hf-Y peaks, the spider diagram is characterized by strong enrichment in LILE. In general, the patterns of the minerals of aillikites essentially differ from the patterns of minerals from carbonatites by slightly lower REE and higher HFSE concentration [38,39] (Figure 18b). 
The clinopyroxenes of high-Al group have asymmetric bell-shaped REE patterns typical of basaltic derivatives, for example of Vitim pyroxenites [55]. The spider diagrams have strong peaks at $\mathrm{Zr}, \mathrm{Hf}, \mathrm{Ta}$, sometimes at $\mathrm{Ba}$, and smaller one at Y. (Figure 18c).

For the kaersutites and pargasites, the REE patterns are essentially higher and slightly less inclined compared to those of Al-augites with higher peaks of $\mathrm{Zr}, \mathrm{Hf}, \mathrm{Ta}, \mathrm{Nb} \mathrm{Ba}, \mathrm{Rb}, \mathrm{Sr}$ (Figure 19b).

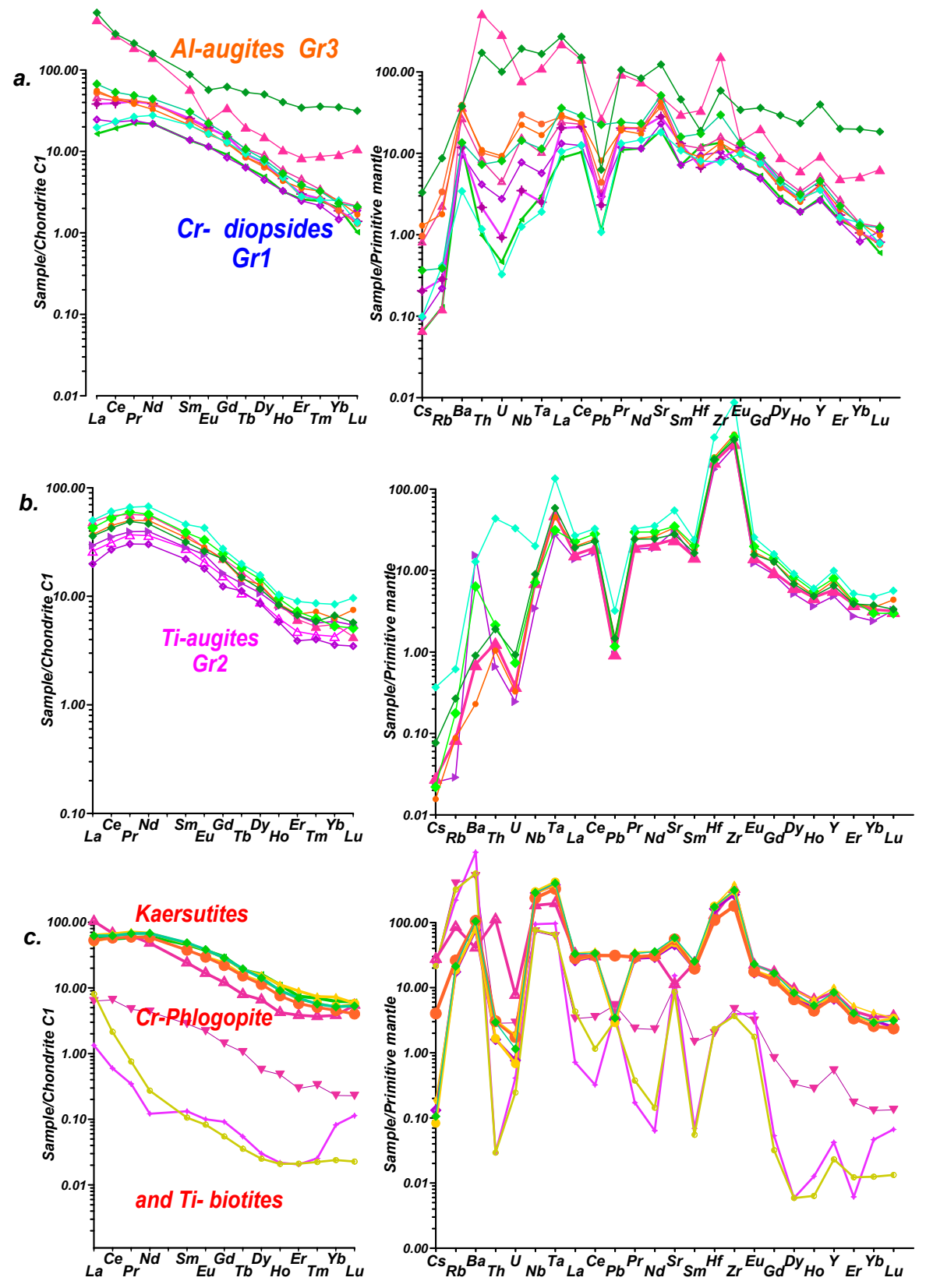

Figure 18. REE patterns and TRE spider diagrams of minerals of aillikites of Yuzhnaya pipe: for Cr-diopsides and Al-augites (a); for Ti-augites (b) for kaersutites and Ti biotites (c). Normalized to primitive mantle [61] and chondrite $\mathrm{C} 1$ [68].

\subsection{The Spectra of Rare Elements in Minerals of Aillikites of BZM}

In those aillikites from the BZM that have a high carbonatite component, the REE levels are often much higher (Figure 19). Carbonate clots and nests in such aillikites contains the minerals that concentrate $\mathrm{REE}, \mathrm{Th}, \mathrm{U}, \mathrm{Ta}, \mathrm{Nb}$, and most often they are perovskite and apatite. The abundance of ore minerals and trace element concentrators and their diversity is much higher in carbonatites $[37,38]$. 
The trace element patterns of Ti-biotites are flat and slightly LREE-rich and often show Eu, $\mathrm{Sr}, \mathrm{Pb}$ maxima. They have relatively high $\mathrm{Nb}$, Ta and slightly lower $\mathrm{Zr}$ and Hf. Perovskites in ore aillikites from BZM show very high level of REE and especially LREE enrichment (to 100000-10000 /C1), and HREE 100 times less. They show the minima of HFSE, with the exception of $\mathrm{Nb}$, as well as for LILE (Figure 19a). The second generation phlogopites are very rich in Ba and in REE, due to tiny fluid inclusions (Figure 19b).

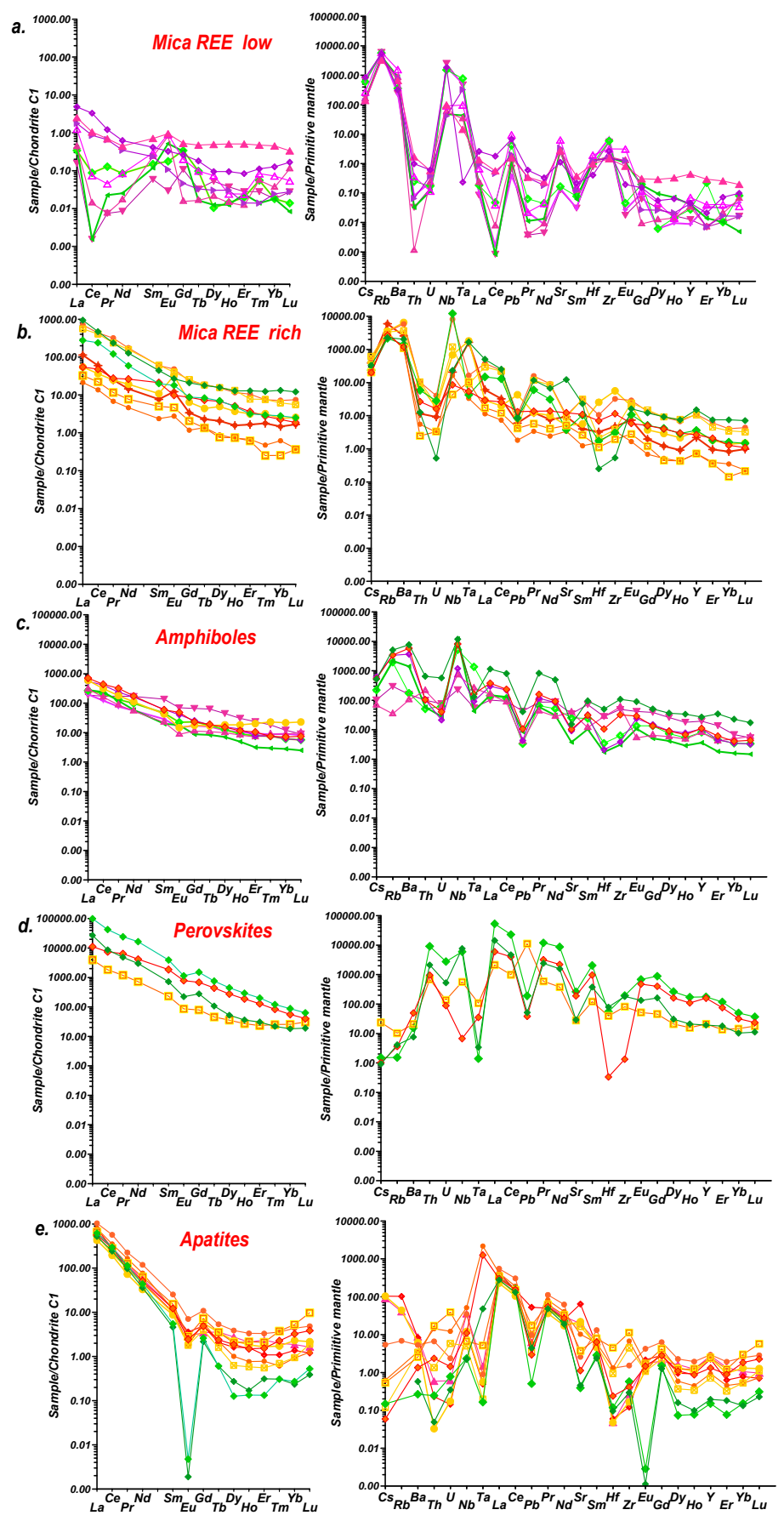

Figure 19. REE patterns and TRE spider diagrams of minerals from aillikites of Beloziminsky massif: for micas low in TRE (a); for micas high in TRE (b); for amphiboles (c); perovskites (d); apatites (e). Normalization to primitive mantle [61] and chondrite C1 [68]. 
Amphiboles are characterized by almost linear and slightly concave REE patterns with La levels at $100-1000 / \mathrm{C} 1$. They have high LILE especially $\mathrm{Ba}, \mathrm{Rb}$ and $\mathrm{Nb}$ peaks (Figure 19c).

In carbonatites apatites have mostly concave downward in HMREE part, probably because BZM carbonatites contain early crystallized grossular garnets that have convex MREE patterns (Figure 19d). Grossular garnets exist more rarely in aillikites.

Since perovskite grains are very small, we often analyzed them in serpentines, carbonates and micas and some diagrams show mixed patterns. Therefore, many analyzed aggregates give patterns enriched in LILE, and minima of HFSE, U, Th which is typical for carbonates (Figure 19d).

Apatite shows inclined REE patterns with a concave HMREE part, often with Eu minima. Some of them are depleted in HFSE, but for others the level of $\mathrm{Zr}, \mathrm{Hf}$ is close to most of REE and TRE. There are patterns low in Th, U, LILE and some very high in Ta (Figure 19e). The intergrowths of apatite with mica are also characterized by the concave arc shaped REE patterns and high contents of LILE and depressions in $\mathrm{Zr}$, Hf and increased $\mathrm{Nb}$, Ta and $\mathrm{Sr}$ levels.

\section{Mineral Thermobarometry}

The PT conditions of the xenocrysts from aillikite dykes from the surroundings and within massif combined with the data for the pyroxenes and amphiboles were calculated using single grain thermobarometry [69-73]. For the Cr-diopsides we used the method of P.Nimis [67]. The PT conditions for the Cr spinels were calculated according to [70,71]. For the typical xenocrysts of Ti augites and high Al pyroxenes the method [71] was used. For the amphiboles, the single grain method [73] was used. Several fields appeared on the diagram (Figure 20).

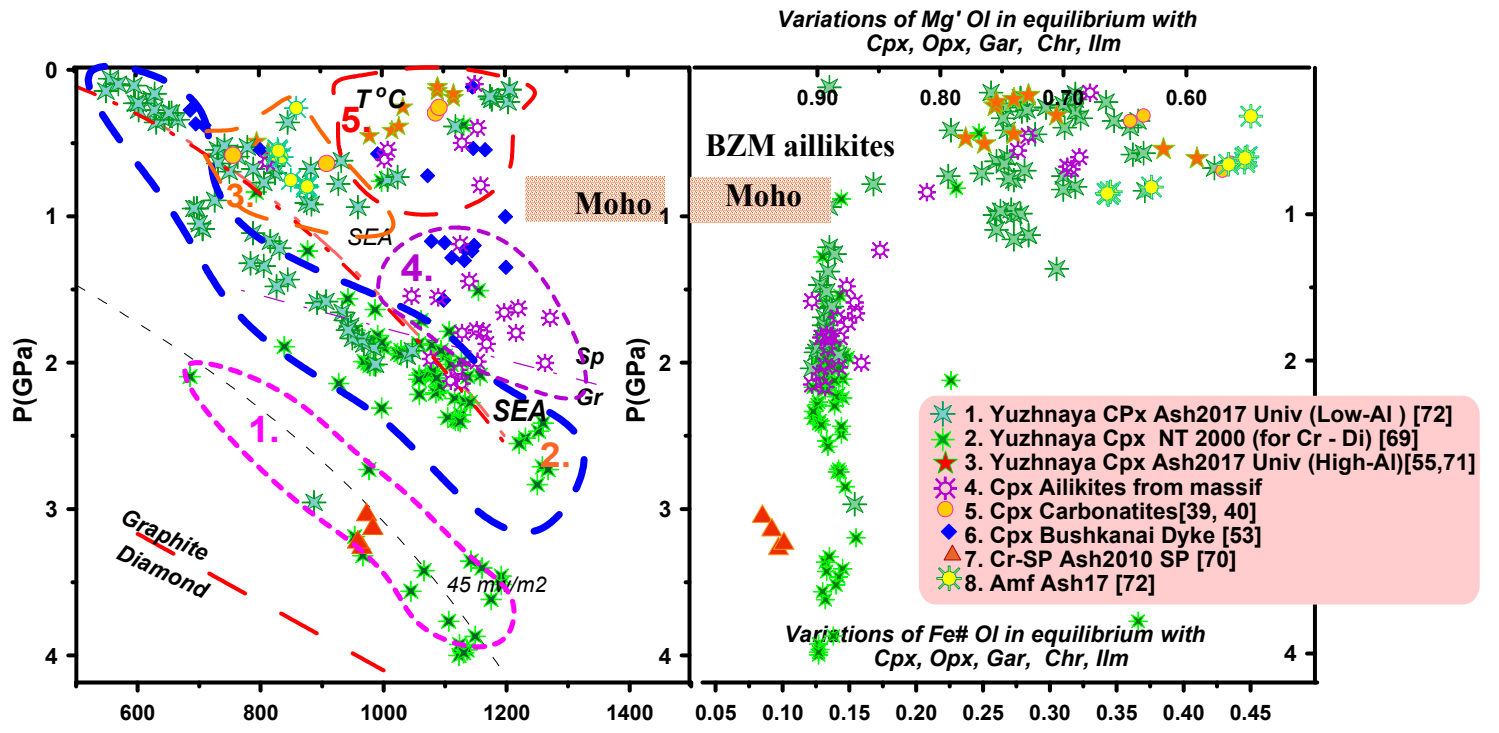

Figure 20. PT conditions for xenocrysts of aillikites BZM defined according to the mono-mineral thermobarometry for Cr-diopsides [69] and other pyroxenes [70-72]; for amphiboles [73] and for Cr-spinels [70].

The first field calculated using xenocryst of $\mathrm{Cr}$-diopsides and chromites using thermobarometric methods $[69,71]$ is located along the high-temperature continental geotherm $\left(45 \mathrm{~mW} / \mathrm{m}^{2}\right)$ in the range of 4-2.2 GPa, referring to conditions of the garnet peridotite mantle facies.

The second field calculated with the single grain pyroxene thermobarometry [72] for xenocrysts of low-alumina clinopyroxenes at the beginning Cr-bearing clinopyroxenes [69] and continued by Mg-augites give the PT trajectory close to the convective geotherm of South-East Australia [62] (SEA) ranging from 2.4 to 0.2 GPa (Figure 20). The third area of clotting of the PT points near the Moho, appears to be consistent with a pause in melt ascent during formation of channels. Crystallization of the low-temperature amphiboles in the pressure range $0.5-1 \mathrm{GPa}$ is related to the crust conditions. The higher temperature 
advective path fourth from mantle to Moho condition is estimated using Cpx from Bushkanai dykes and Cpx from the BZM massif. The fifth field composed with Al-augites and amphiboles (up to $1200^{\circ} \mathrm{C}$ ) corresponds to crustal conditions.

\section{Discussion}

\subsection{Reasons for Variations of Bulk Rock Compositions}

Bulk rock major element compositions of many of BZM aillikites shows the high deviation from the primitive group 1 mainly due to deviations in $\mathrm{SiO}_{2}$ regulated by carbonate or serpentine admixtures. Some of them are rich in carbonates. Cognate carbonates occur in all rocks but in most cases, these are xenogenic carbonates (or fragments of carbonatites), which contain also abundant ores and TRE-rich minerals.

Several Mg-rich varieties contain xenoliths of mantle rocks such as serpentinites containing chromites, sulfides and phlogopites also mainly carbonatized. In addition, small amount of varieties which are lower in Mg may relate to melts mixed with the later carbonatites captured as xenoliths. Thus the primary variations in the mantle sources and probably accompanied by differentiation are accompanied by the admixture of several sources: Mg-rich dunites, carbonatites, phlogopites $\left(\mathrm{K}_{2} \mathrm{O}\right)$, sulfides and suggested subduction-related metasomatites which could include the mature crust sediments with the concentrators of TRE- monazites, zircons, ilmenite, rutiles, $\mathrm{MnO}$ oxides etc. And the plume source could essentially influence the melt compositions by addition of $\mathrm{TiO} 2, \mathrm{PGE}, \mathrm{Ni}$ and other magmaphile elements.

Trace element compositions. High inclination of the REE patterns of primitive BZM melts indicates their formation within the garnet facie of the upper mantle. The TRE spiderdiagrams of YuP and similar rocks are close to the alkaline basalts, minettes, even kimberlites suggesting which occurs by low degree melting with (1-0.1\%) of primitive mantle source [61] in a presence of volatiles proved by high content of LILE elements and $\mathrm{Sr}$, Pb peaks.

Trace element spider diagrams for bulk rock compositions (Figure 18) allowed us to separate the aillikites into 7 groups, which are related to the groups divided in the TAS diagram. The spider diagrams for the rocks of the BZM are more enriched in REE and TRE than aillikites from Aillik Bay Labrador $[7,13]$. As well, $\mathrm{K}_{2} \mathrm{O}$ is regulated mainly by phlogopites and $\mathrm{Na}_{2} \mathrm{O}$ by the carbonates and clinopyroxenes, whereas $\mathrm{CaO}$ is mainly determined by calcite abundance. The high in $\mathrm{CaO}$ and $\mathrm{CO}_{2}$ (and $\mathrm{H}_{2} \mathrm{O}$ ) are often closer to carbonatites.

Enrichment in TRE is mainly determined mainly by differences in the compositions of accessory minerals such as zircons, perovskites, Ta-niobates, thorites and apatites etc., which mainly are segregated in the carbonate-rich portions of the rocks. Their content is lower in phlogopite-dominated where apatites are more common than monazites and perovskites. The Ti-magnetites sometimes very enriched in $\mathrm{Nb}, \mathrm{Mn}$, also influence the compositions for $\mathrm{CaO}$-rich rocks.

Comparing groups 1 and 3 (Figure 18a), it is clear that the latter is enriched in trace elements due to addition of amphiboles and perovskites. The REE-enrichment of group 4 is due to the high concentration of REE in the apatite. The peaks in Th in Group 2 (Figure 18b) may be the only results of contamination with some Th minerals as monazites or together with the zircons. In contrast, the high abundance of the HFSE such as Nb, Ta together with the high LILE may be result of the high abundance of late-formed perovskites (Figure 12c).

Possible fractionation processes including precipitations of olivines and pyroxenes should take place which is proved by the trends of the clinopyroxenes and their high variations. The modeling of the partial melting and fractionation will be in discussed in future publications.

\subsection{Reasons of Variations of Mineral Compositions}

The groups of the pyroxenes are determined not only the variations of the chemistry of parental melts but also depends on thermobarometric conditions [63,69-73]. 
The trend for Gr1 reflects the interaction of mantle rocks with the very Mg-rich melts or fluids because interaction with plume and subduction-related melts should essentially increase $\mathrm{Fe}^{\prime}$, $\mathrm{Ti}$ and $\mathrm{Al}$, which is visible for the xenocrysts of Cr-diopsides from Bushkanai dyke [53].

The $\mathrm{Gr} 2 \mathrm{Cpx}$ of joint increase of magamphile $\mathrm{FeO}, \mathrm{TiO}_{2}$, represents the fractionation trend which is formed by the rising fractionation trends during the creation of the magmatic channels like for most alkali basalts [55]. It is controlled mainly by joint Cpx-Ol crystallization. This is proved by the thermobarometric estimates (Figure 20). The Gr3 dominated by Al-rich fassaite according to thermobarometry was formed in relatively shallow depths (see Figure 20). Late xenocrysts of Fe-rich amphiboles from YuP according to thermobarometry were probably formed near Moho or in shallow conditions the crust [72,73]. The path fourth represents the path of late mainly plume-related melts from ailikite of the massif and Bushkanai dyke, corresponding conditions of the last melt portion sub-adiabatically ascending from the region of interaction to the Moho. The melts that created the fifth series were silicate-carbonatite or substantially carbonatitic. Their intrusion above the Moho caused the appearance of magma chambers where stratified intrusions with $\mathrm{Al}$-augites and amphiboles (up to $1200^{\circ} \mathrm{C}$ ) generated the syenitic and layered alkaline silicate carbonatitic magmas probably due to interaction with the crust. They possibly have supplied the BZM and generated series of contrast rocks (Figure 21).

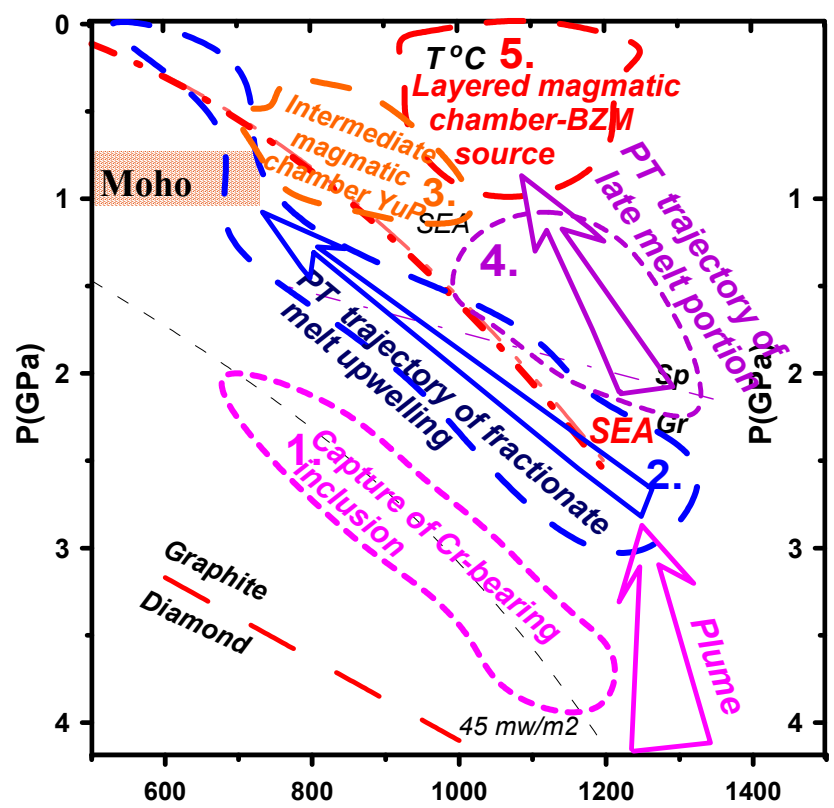

Figure 21. Scheme of PT evolution mantle melts according to thermobarmetry.

The series of the of the phlogopites and biotites show the trend between the aillikites (carbonate + phlogopite) and lamproites (phlogopites +olivine) source (Figure 15).

Olivines with high $\mathrm{Mg}^{\prime}$ and low $\mathrm{CaO}$ are probably xenogenic. Those higher $\mathrm{CaO}$ content to $0.4 \mathrm{wt} \%$ are rather high temperature or were formed from the Ca-rich melts. The olivines contain $\mathrm{MnO}$ to $4-6 \mathrm{wt} \%$, probably due to mixing with carbonatitic material which is enriched in crustal subduction components (Figure 16).

The reasons of the ilmenite variations reflect relatively high oxygen conditions (Figure 17) and the high $\mathrm{Mn}, \mathrm{Zr}$ and $\mathrm{Nb}$ varieties reflect the various sources of BZM carbonatite-silicate melts.

The trace elements of minerals. The $\mathrm{Cpx}$ from YuP show high difference between $\mathrm{Gr} 1 \mathrm{Cr}$ diopsides with have very high REE levels with the concave pattern evidences about the LREE from the fluids and also abundance of subduction-related components U, Ba, Sr [74-77] (Figure 18). The Gr2 augites show the signs of fractionation with conformable patterns of REE and TRE spider diagrams. The peaks in HFSE suggest the contaminations of the parental melts in concentrators such as ilmenites or perovskites 
from mantle metasomatites. Very REE-enriched patterns of Al-rich augites and Eu anomalies suggest a possible origin from the carbonatite melt in relatively low-pressure conditions in Moho or crust.

Calculated with the partition coefficients $(\mathrm{Kd})$ for the silicate melts [78] for melts in equilibrium with CPX gives to high level of La and other REE to $10^{6}$ relative to chondrite $\mathrm{C} 1$. Using the carbonatite Kd [79] the calculated compositions which enrich the melts of Gr4 have low HFSE and LILE should be essentially evolved carbonatitic melts. But calculated melts in equilibrium with Cr-diopsides (Gr1) and Ti-augites are much higher in these components especially in Ba and have concave downward patterns and one order higher $\mathrm{La} / \mathrm{Yb}_{\mathrm{n}}$ ratios (Figure 22) which suggests possibly participation of high density fluid [80] having such ratios.

In BZM massif observed very high level of REE and HFSE (Figure 19) is determined by the high concentrations of incompatible elements in the evolved carbonatites melt pockets. Abundance of melt and fluid inclusions in the late silicate minerals determines also strong LREE-enrichment associated with abundance of volatiles.

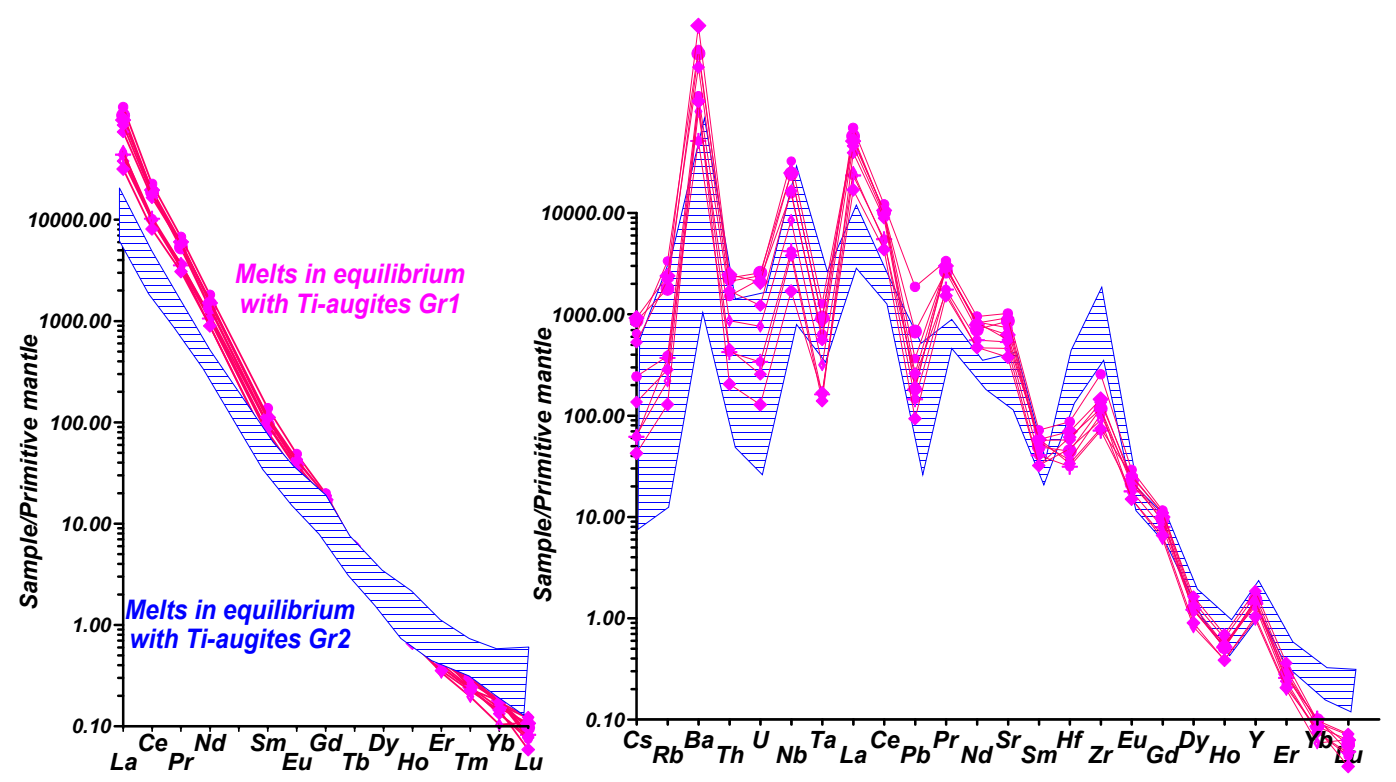

Figure 22. REE and TRE spectra of the melts in equilibrium with the Cpx from YUP Gr1-2 calculated with the partition coefficients after [79]. Normalized to primitive mantle [61] and chondrite C1 [68].

\subsection{Problems of Origin of Aillikites and Ultramafic Lamprophyres}

The origin of aillikites cover huge range of interrelated problems including subduction and fluid metasomatism [64,65,74], magmatic plume melts interaction [81], partial melting of the mantle [68], magmatic evolution, including fractionation [82] and suggesting wall rock assimilation (AFC) [83] and possible magmatic immiscibility at the mantle level $[30,78]$ which all together determine the wide series and a rather unstable composition of the aillikite rock series.

Genesis of Belaya Zima aillikites in carbonatite massif and other similar massifs in Southern Siberia $[6,21,34-46,48-53]$ and worldwide $[1-3,7,8,10,12,13,27-29,57,79,81,84-86]$ are widely discussed.

The aillikites occur in three, major groups: 1 -as part of alkaline ultrabasic carbonatite complexes [1-3,10-12,15,79,80,86] or massifs, 2-in association with the kimberlites $[5,7,13,29,57,87-89]$, or form independent intrusions $[23,27]$ and they differ in compositions in mineralogy. The first group is closer to carbonatites and enriched in TRE and REE and apatite (phosphorus) and HFSE. The second group is more enriched in $\mathrm{Mg}$ and $\mathrm{TiO}_{2}$, and the third series appears to be more alkaline.

In turn, aillikites from carbonatite ultramafic massifs differ from the silicate-carbonatites P-rich rocks called phoscorites [89-93] that are found in many carbonatite massifs. Phoscorites do not contain any chrome-rich minerals and have high $\mathrm{FeO}$ (more than $20 \mathrm{wt} \%$ ) and low $\mathrm{Mg}^{\prime}$ [90-92]. Our studied aillikite rock series have no pyrochlore-group minerals, typical of carbonatites of the BZM [38,39] but 
contains a lot of $\mathrm{Cr}$ minerals. Phoscorites and other carbonatites have been suggested to be immiscible melts, which may be derived from the primary homogeneous alkali carbonatite-silicate melt [30] which possibly occur at the crust level during carbonatitic magma differentiation abundance in $\mathrm{P}$ is possibly the critical factor of such immiscibility. Such phoscorites are evidently higher in REE [91-94] which distributed to apatites.

Experimental evidence of such of carbonates immiscibility [95-99] exists for relatively shallow pressures 75-100 MPa [97] in the crust show that such magmas do not contain high concentration of ore components.

\subsection{Mantle Roots of the Alkaline Ultramafic Carbonatitic Massifs in Southern Siberia}

In mantle conditions, liquid immiscibility and separation of carbonates was experimentally obtained for relatively low temperatures $1100{ }^{\circ} \mathrm{C}$ at pressures $3-5 \mathrm{GPa}[30,79,100]$ and more, which are similar to the conditions for Cr-bearing inclusions in Yuzhnaya pipe, which corresponds exactly to the region of mantle xenolith and inclusions capture in Torngat, Labrador $[7,29,57]$ and BZM. Similar or slightly higher pressures were determined for the aillikites of Scotland [23] and Eastern Antarctica [89].

Primitive aillikites in BZM often have a very high $\mathrm{Mg}^{\prime} \sim 0.69 \mathrm{YuP}$ and more for many other varieties which for silicate magmas is very high, almost close to komatiites or boninites [101]. Only some olivines $\mathrm{Mg}^{\prime} \sim 0.89$ are in equilibrium, the others as well as Cpx with $\mathrm{Mg}^{\prime} \sim 0.85-0.8$ are more Fe-rich and fractionated. All Cr-bearing Al-rich Cpx, kaersutites and Ti-micas are derived from different melt portions and are xenocrysts. Consequently, magmas may originally have been less $\mathrm{Mg}$-rich and then dissolved magnesium material (olivines or dunites). The probability of assimilation is very high, because carbonated dunite xenoliths in YuP are abundant and apparently influenced the bulk composition of the rock.

\subsection{Processes in Mantle Source for BZM and Evolution of Aillikite Melts}

There are three main hypotheses of the origin for aillikites and related rocks: (1) melting of carbonated peridotites [100,102]; (2) assimilation of carbonated phlogopite metasomatites [30,100,103,104] by plume silicate melts; (3) mixing of carbonatites with silicate melts in the mantle or assimilation of mantle material by carbonatites $[3,30,100]$. Presence of carbonates in melt inclusions from YuP [52,105-107] in olivines as well for other massifs [108] supports the first two suggestions rather than the third because olivine is not on the liquidus of carbonatites. For the alkaline carbonatite complexes there are many evidences of the action of plume melts $[3,10,13,21,28,81,102,109]$ and melting the phlogopite metasomatized and carbonated mantle [100].

In the PT diagram (Figures 20 and 21), the source mantle region shows a heated conductive geotherm. But the heating to SEA geotherm may be the only product of the heating by plume and upwelling of the melts to 2.5 from $4 \mathrm{GPa}$, further creating a fractionation path along the SEA. The next array 3 on the diagram possibly refers to the rapid fractionation of amphiboles and clinopyroxenes and then crystallization of the groundmass pyroxenes. The geochemistry of the mantle minerals shows very high enrichments of the YuP xenocrysts in REE and TRE elements (Figure 18). The sulfide components were present in the dunite inclusions.

The fields 4 and 5 on the diagram refer to the more rapid ascent of the later plume melts to the Moho and then formation of the shallow mantle magma chamber where differentiation of the primary magmas could occur and separation of the relatively enriched fluids and fractional crystallization and finally creation of the ultramafic carbonatite complex. The large silicate masses possibly were left by magma in the intermediate magma chambers in the lower crust (Field 5) and further moved mainly carbonatitic melts in several stages. Later phases in the massif are much more enriched in TRE compositions (Figure 18).

The time span of about $25 \mathrm{Ma}$ for the evolution of the aillikites in BZM and overall time $>65 \mathrm{Ma}$ provide evidence for the long developing of the carbonatite ultramafic massifs comparable with the common periodicity of the plumes and tectonic geological processes close to $65 \mathrm{Ma}[109,110]$. 


\subsection{The Source of the Ore Substance}

The $\mathrm{Cu}-\mathrm{Zn}$ ores as well as Ta-Nb, Th-U and REE specialization and high MnO content evidences about the complex origin of the ore components in BZM. High alkalis, carbonates, high $\mathrm{H}_{2} \mathrm{O}$ associated with $\mathrm{Ba}, \mathrm{Sr}, \mathrm{U}, \mathrm{Pb}, \mathrm{Zn}, \mathrm{Cu}, \mathrm{Au}, \mathrm{Ag}$ are often considered to be a subduction-related fluid metasomatism [64,74,76,77,111,112]. However, the rare earths and elements such as $\mathrm{Nb}, \mathrm{Ta}, \mathrm{Zr}, \mathrm{Hf}, \mathrm{Ti}$, are not commonly attributed to subduction $[3,8,14,74,76]$ though the remobilization of the subducted crustal sediments can be a possible source of HFSE and other elements [2,76]. All these elements are concentrated in the perovskites and may be the result of re-melting of specific metasomatic fronts, which occur around essentially carbonatitic melts such as protokimberlites [112]. The source of the phosphorus is also debatable [89,91,113]. The partition of the components between the silicate and immiscible carbonatite liquid also may be the reason of the enrichment in HFSE, P and other elements [76,85,90,91]. Breakdown of the silicate magma and carbonatite at depth of about $4.0 \mathrm{GPa}$ and in crust conditions $[30,70]$ may contribute to the concentration of ore material.

Such processes of interaction of plumes and metasomatized mantle were the reason of formation of ultramafic carbonatite complexes worldwide [1-5,7,8,11-14,18,22,26,29,32,38,39,57,81,86,88,89,109] and in Siberia $[4,34-56,58,59,105-107,110]$. An additional source can be considered the transfer of some components (LREE, LILE) by fluxes of volatiles, or melts that are saturated in volatiles [77,107,108,111]. One of the effective mechanisms of concentration of ore components, including rare-metals and radioactive elements, is multi-stage small degrees melting of carbonated mantle and crystallization with the formation of a metasomatic front, abundant in carbonates, perovskite, apatite, along with ilmenite and mica [112]. Such metasomatites are suggested to be associated with protokimberlite melts, which are essentially carbonatitic in final stage near $4.0 \mathrm{GPa}[30,100]$. But in the final stages, decarbonation reactions cause increased concentrations of the REE and TRE in fluids [114].

Presumably, a group of carbonate metasomatites with high REE and TRE content melted, which arose due to the contamination of aillikites with perovskite and ilmenite and Ba-Sr mica. Additional differentiation at the level of Moho and in shallow chambers with separation into carbonatite and silicate components after significant crystallization differentiation should lead to the concentration of rare elements in carbonatites especially if they contain phosphorus [76,85,90-94]. There is a separation of the association into two groups: (1) with apatite and micas with Ba-Sr-LREE specialization and (2) the perovskite and minerals of $\mathrm{U}-\mathrm{Th}, \mathrm{Ta}-\mathrm{Nb}, \mathrm{Zr}-\mathrm{Hf}$ in association with carbonates. It indicates the participation of different types of melts and volatiles in the process of ore formation. However, it can be assumed that deep carbonatite melts associated with the plume or superplume could also be substantially enriched with $\mathrm{Ti}$ and other HFSE. There was high oxidation of the magma in the final stage because magnetite is one of the most widespread minerals in the aillikites in massif. Hence the aillikitic and carbonatitic magmas essentially differed in oxidation stage from the initial magmatic conditions [113].

\section{Conclusions}

1. Aillikites from BZM complex containing primary mantle material as xenocrysts are characterized by a wide range of compositions from ijolites to Phl carbonatites.

2. The mantle xenocrysts give the pressures of the aillikite origin $>4.0 \mathrm{GPa}$ and the PT path corresponding to convective $90 \mathrm{~mW} / \mathrm{m}^{2}$ geotherm and probably separate magma chambers near Moho and above.

3. Deep-seated minerals in mantle level were originally enriched in HFSE and LILE.

4. Additional enrichment of aillikites in ore minerals occurred due to mixing with carbonatites.

Supplementary Materials: The following are available online at http://www.mdpi.com/2075-163X/10/5/404/s1, Table S1: Measurements of Ar isotopic compositions; Table S2: Bulk rocks major and TRE composition; Table S3: EPMA minerals, electron microscope analyses of minerals; Table S4: TRE in minerals.

Author Contributions: Sample acquisition, I.A., S.Z., D.B., O.N.K. Conceptualization, I.A. and S.Z. Methodology, N.M.; A.T., D.Y., N.S.K. Validation, I.A. and S.Z. Formal analysis, N.M., A.T., D.Y., N.S.K. Investigation, I.A., S.Z., D.B. Resources, I.A. and S.Z. Data curation, N.M., A.T., N.K., I.A. and S.Z. Writing-original draft preparation, 
I.A. Writing-review and editing, I.A., S.Z., H.D. Visualization, I.A. Supervision, I.A., S.Z. Project administration, I.A., S.Z., O.N.K. Funding acquisition, I.A., S.Z. All authors have read and agreed to the published version of the manuscript.

Funding: The fieldwork and some geochemical analyses were performed on government assignment to the V.S. Sobolev Institute of Geology and Mineralogy, at the Analytical Center for Multi-Elemental and Isotope Research (Novosibirsk, Russia). Supported by RFBR grants 19-05-00788, 18-05-00211, 16-05-00860a, 16-05-00737a, 15-05-06950a and partially by Russian Science Foundation (grant 18-17-00120)—definition of radioactive (U, Th, K) elements in samples by gamma-spectrometry and comparative analysis of the lamprophyres of the Tomtor massif and Belaya Zima and Labrador). Work is done on state assignment of IGM SB RAS.

Acknowledgments: The authors are grateful for consultations to N.V. Vladykin, V.V. Yarmolyuk. The authors also wish to thank the anonymous reviewers for helping to improve the structure and content of the paper.

Conflicts of Interest: The authors declare no conflict of interest.

\section{References}

1. Rock, N.M.S. Lamprophyres; Springer: Berlin, Germany, 1991; 224p.

2. Francis, D.; Patterson, M. Kimberlites and aillikites as probes of the continental lithospheric mantle. Lithos 2009, 109, 72-80. [CrossRef]

3. Pirajno, F. Intracontinental anorogenic alkaline magmatism and carbonatites, associated mineral systems and the mantle plume connection. Gondwana Res. 2015, 27, 1181-1216. [CrossRef]

4. Woolley, A.R.; Kjarsgaard, B.A. Paragenetic types of carbonatite as indicated by the diversity and relative abundances of associated silicate rocks: Evidence from a global database. Can. Mineral. 2008, 46, 741-752. [CrossRef]

5. Smith, C.B.; Haggerty, S.E.; Chatterjee, B.; Beard, A.; Townend, R. Kimberlite, lamproite, ultramafic lamprophyre, and carbonatite relationships on the Dharwar Craton, India; an example from the Khaderpet pipe, a diamondiferous ultramafic with associated carbonatite intrusion. Lithos 2013, 182-183, 102-113. [CrossRef]

6. Vladykin, N.V. Potassium alkaline lamproite-carbonatite complexes: Petrology, genesis, and ore reserves. Russ. Geol. Geophys. 2009, 50, 1119-1128. [CrossRef]

7. Tappe, S.; Foley, S.F.; Jenner, G.A.; Heaman, L.M.; Kjarsgaard, B.A.; Romer, R.L.; Stracke, A.; Joyce, N.; Hoefs, J. Genesis of ultramafic lamprophyres and carbonatites at Aillik Bay, Labrador: A consequence of incipient lithospheric thinning beneath the North Atlantic craton. J. Petrol. 2006, 47, 1261-1315. [CrossRef]

8. Yunshuai Li, Y.; Zhang, J.; Mostofa, K.M.G.; Wang, Y.; Yu, S.; Cai, Z.; Lia, P.; Zhou, G.; Fu, C.; Mao, X. Petrogenesis of carbonatites in the Luliangshan region, North Qaidam, northern Tibet, China: Evidence for recycling of sedimentary carbonate and mantle metasomatism within a subduction zone. Lithos 2018, 322, 148-165.

9. Torsvik, T.H.; Cocks, L.R.M. Earth History and Paleogeography; Cambridge University Press: Cambridge, UK, 2016; 317p.

10. Yarmolyuk, V.V.; Kovalenko, V.I.; Sal'nikova, E.B.; Nikiforov, A.V.; Kotov, A.B.; Vladykin, N.V. Late., Late Riphean Rifting and Breakup of Laurasia: Data on Geochronological Studies of Ultramafic Alkaline Complexes in the Southern Framing of the Siberian Craton. Doklady Earth Sci. 2005, 404, 1031-1036.

11. Cordeiro, P.F.O.; Brod Jos, A.; Dantas, E.L.; Barbosa, E.S.R. Mineral chemistry, isotope geochemistry and petrogenesis of niobium-rich rocks from the Catalo I carbonatite-phoscorites complex, Central Brazil. Lithos 2010, 118, 223-237. [CrossRef]

12. Chmyz, L.; Arnaud, N.; Biondi, J.C.; Azzone, R.G.; Bosch, D. Hf-Pb isotope and trace element constraints on the origin of the Jacupiranga Complex (Brazil): Insights into carbonatite genesis and multi-stage metasomatism of the lithospheric mantle. Gondwana Res. 2019, 71, 16-27. [CrossRef]

13. Tappe, S.; Branda, N.B.; Stracke, A.; van Acken, D.; Liu, C.-Z.; Strauss, H.; Wue, F.-Y.; Lugue, A.; Mitchell, R.H. Plates or plumes in the origin of kimberlites: $\mathrm{U} / \mathrm{Pb}$ perovskite and $\mathrm{Sr}-\mathrm{Nd}-\mathrm{Hf}-\mathrm{Os}-\mathrm{C}-\mathrm{O}$ isotope constraints from the Superior craton (Canada). Chem. Geol. 2017, 20, 57-58. [CrossRef]

14. D’Orazio, M.; Innocenti, F.; Tonarini, S. Doglioni, Carbonatites in a subduction system: The Pleistocene alvikites from Mt. Vulture (southern Italy). Lithos 2007, 98, 313-334. [CrossRef]

15. Mattsson, H.B.; Karin, H.; Carlsson, M.; Malehmir, M. The role of mafic dykes in the petrogenesis of the Archean Siilinjärvi carbonatite complex, east-central Finland. Lithos 2019, 342-343, 468-479. [CrossRef] 
16. Berger, M.; Rollinson, H. Isotopic and geochemical evidence for crust-mantle interaction during late Archaean crustal growth. Geochim. Cosmochim. Acta 1997, 61, 4809-4829. [CrossRef]

17. Nicklas, R.W.; Puchtel, I.S.; Ash, R.D.; Piccoli, P.M.; Anbar, D. Secular mantle oxidation across the Archean-Proterozoic boundary: Evidence from V partitioning in komatiites and picrites. Geochim. Cosmochim. Acta 2019, 2501, 49-75. [CrossRef]

18. Woodard, J.; Huhma, H. Paleoproterozoic mantle enrichment beneath the Fennoscandian Shield: Isotopic insight from carbonatites and lamprophyres. Lithos 2015, 236-237, 311-323. [CrossRef]

19. Dongre, A.; Tappe, S. Kimberlite and carbonatite dykes within the Premier diatreme root (Cullinan Diamond Mine, South Africa): New insights to mineralogical-genetic classifications and magma $\mathrm{CO}_{2}$ degassing. Lithos 2019, 338-339, 155-173. [CrossRef]

20. Nielsen, T.F.D.; Jensen, S.M.; Secher, K.; Sand, K.K. Distribution of kimberlite and aillikite in the Diamond Province of southern West Greenland: A regional perspective based on groundmass mineral chemistry and bulk compositions. Lithos 2009, 112 (Suppl. 1), 358-378. [CrossRef]

21. Yarmolyuk, V.V.; Kuzmin, M.I.; Ernst, R.E. Intraplate geodynamics and magmatism in the evolution of the Central Asian Orogenic Belt. J. Asian Earth Sci. 2014, 93, 158-179. [CrossRef]

22. Beard, A.D.; Vetrin, V.; Kempton., D.; Maluskid, H. Petrogenesis of Devonian lamprophyre and carbonatite minor intrusions, Kandalaksha Gulf (Kola Peninsula, Russia). Lithos 1996, 39, 93-119. [CrossRef]

23. Hutchison, M.T.; Faithfull, J.W.; Barfod, D.N.; Hughes, J.W.; Upton, B.G.J. The mantle of Scotland viewed through the Glen Gollaidh aillikite. Mineral. Petrol. 2019, 112, 115-132. [CrossRef]

24. Maria, A.H.; Denny, B.F.; DiPietro, J.A.; Howard, K.F.; King, M.D. Geochemistry and Sr-Nd isotopic compositions of Permian ultramafic lamprophyres in the Reelfoot Rift - Rough Creek Graben, southern Illinois and northwestern Kentucky. Lithos 2019, 340-341, 191-201. [CrossRef]

25. Kargin, A.V.; Golubeva, Y.Y.; Demonterova, E.I.; Koval'chuk, E.V. Petrographic-geochemical types of Triassic alkaline ultramafic rocks in the Northern Anabar province, Yakutia, Russia. Petrology 2017, 25, 535-565. [CrossRef]

26. Krüger, J.C.; Romer, R.L.; Kämpf, H. Late Cretaceous ultramafic lamprophyres and carbonatites from the Delitzsch Complex, Germany. Chem. Geol. 2013, 353, 140-150. [CrossRef]

27. Upton, B.G.J.; Craven, J.A.; Kirstein, L.A. Crystallisation of mela-aillikites of the Narsaq region, Gardar alkaline province, south Greenland and relationships to other aillikitic-carbonatitic associations in the province. Lithos 2006, 92, 300-319. [CrossRef]

28. Pandey, R.; Pandey, A.; Chalapathi Rao, N.V.; Belyatsky, B.; Choudhary, A.K.; Lehmann, B.; Dinesh Pandit, D.; Dhote, P. Petrogenesis of end-Cretaceous/Early Eocene lamprophyres from the Deccan Large Igneous Province: Constraints on plume-lithosphere interaction and the post-Deccan lithosphere-asthenosphere boundary (LAB) beneath NW India. Lithos 2019, 346-347, 105-139. [CrossRef]

29. Tappe, S.; Foley, S.F.; Kjarsgaard, B.A.; Romer, R.L.; Heaman, L.M.; Stracke, A.; Jenner, G.A. Between carbonatite and lamproite-diamondiferous Torngat ultramafic lamprophyres formed by carbonate-fluxed melting of cratonic MARID-type metasomes. Geochim. Et Cosmochim. Acta 2008, 72, 3258-3286. [CrossRef]

30. Foley, S.F.; Pinter, Z. Primary melt compositions in the Earth's mantle. In Magmas Under Pressure; Elsevier Inc.: Amsterdam, The Netherlands, 2018; pp. 3-42.

31. Kargin, A.V.; Nosova, A.A.; Postnikov, A.V.; Chugaev, A.V.; Postnikova, O.V.; Popova, L.P.; Poshibaev, V.V.; Sazonova, L.V.; Dokuchaev, A.Y.; Smirnova, M.D. Devonian ultramafic lamprophyre in the Irkineeva-Chadobets trough in the southwest of the Siberian Platform: Age, composition, and implications for diamond potential prediction. Geol. Ore Depos. 2016, 58, 383-384. [CrossRef]

32. Zaitzev, A.N.; Willaims, T.; Jeffries, T.; Strekopytov, S.; Moutte, J.; Ivashchenkova, O.V.; Spratt, J.; Petrov, S.V.; Wall, F.; Seltmann, R.; et al. Rare earth elements in phoscorites and carbonatites of the Devonian Kola Alkaline Province, Russia: Examples from Kovdor, Khibina, Vuoriyarvi and Turiy Mys complexes. Ore Geol. Rev. 2014, 61, 204-225. [CrossRef]

33. Nosova, A.A.; Sazonova, L.V.; Kargin, A.V.; Smirnova, M.D.; Lapin, A.V.; Shcherbakov, V.D. Olivine in ultramafic lamprophyres: Chemistry, crystallisation, and melt sources of Siberian Pre-and post-trap aillikites. Contrib. Mineral. Petrol. 2018, 173, 55. [CrossRef] 
34. Bagdasarov, Y.A. Phosphate-rare metal carbonatites of the Belaya Zima Massif (Eastern Sayan, Russia). Geol. Ore Depos. 2002, 44, 132-141.

35. Kolesnikov, A.V.; Anisimova, Z.M. Geological Map of USSR. List N-47-XXIII; Irkutsk geological Department: Irkutsk, Russia, 1961.

36. Frolov, A.; Belov, S.V. Complex carbonate deposits of the Ziminsky ore district (East Sayan, Russia). Geol. Ore Depos. 1999, 41, 109-130.

37. Pozharitskaya, L.K.; Samoilov, V.S. Petrologiya, mineralogiya, I geokhimiya karbonatitov Vostochnoi Sibiri (Petrology, Mineralogy and Geochemistry of Carbonatites from East Siberia); Nauka: Moscow, Russia, 1972; 254p.

38. Doroshkevich, A.G.; Veksler, I.V.; Izbrodin, I.A.; Ripp, G.S.; Khromova, E.A.; Posokhov, V.F.; Travin, A.V.; Vladykin, N.V. Stable isotope composition of minerals in the Belaya Zima plutonic complex, Russia: Implications for the sources of the parental magma and metasomatizing fluids. J. Asian Earth Sci. 2016, 116, 81-96. [CrossRef]

39. Doroshkevich, A.G.; Veksler, I.V.; Klemd, R.; Khromova, E.A.; Izbrodin, I.A. Trace-element composition of minerals and rocks in the Belaya Zima carbonatite complex (Russia): Implications for the mechanisms of magma evolution and carbonatite formation. Lithos 2017, 284-285, 91-108. [CrossRef]

40. Chernysheva, E.A.; Konusova, V.V.; Smirnova, E.V.; Chuvashova, L.A. Differentiation of rare-earth elements in alkaline rocks of the low-lying carbonite complex. Dokl. USSR Acad. Sci. 1989, 305, 438-442.

41. Andreeva, I.A.; Kovalenko, V.I.; Nikiforov, A.V.; Kononkova, N.N. Compositions of magmas, formation conditions, and genesis of carbonate-bearing ijolites and carbonatites of the Belaya Zima alkaline carbonatite complex, Eastern Sayan. Petrology 2007, 15, 551-574. [CrossRef]

42. Chernysheva, E.A.; Belozerova, O.Y. Composition of deep-seated xenoliths from melilitites and certain characteristics of primary alkaline melt evolution in Nizhnesaynsky carbonatite complex. Geochemistry 2000, 7, 785-789.

43. Travin, A.V.; Ashchepkov, I.V.; Udin, D.; Prostyakov, K. Laser and stepwise-heating ${ }^{40} \mathrm{Ar} /{ }^{39} \mathrm{Ar}$ dating of kimberlite-like rocks from Sayan Foothills and peripheral part of the Siberian platform. In Proceedings of the 12th Annual, V.M. Goldschmidt Conference, Davos, Switzerland, 18-23 August 2002; A783.

44. Bagdasarov, Y.A.; Zhuravlev, D.Z. Neodymium and Strontium Isotope Composition in the Ores of the Ingili-Algama Cluster, East Aldan, and Problems of their Genesis. Geochem. Int. 1994, 11, 1668-1673.

45. Sharygin, V.V.; Doroshkevich, A.G.; Khrolmova, E.A. Nb-Fe-group minerals zirconolite in calcium Beloziminsky carbonatite massif (East Sayan). Mineralogy 2016, 4, 3-18.

46. Khromova, E.A.; Doroshkevich, A.G.; Sharygin, V.V.; Izbrodin, L.A. Compositional Evolution of pyrochloree-Group Minerals in Carbonatites of the Belaya Zima Pluton, Eastern Sayan. Geol. Ore Depos. 2017, 59, 752-764. [CrossRef]

47. Panina, L.I.; Rokosova, E.; Isakova, A.T.; Tolstov, A.V. Trace Elements in Alkaline Lamprophyres, Clinopyroxene, and Amphibole of the Tomtor Massif and the Ore Potential of the Melts. Geochem. Int. 2018, 56, 651-669. [CrossRef]

48. Gladkochub, D.P.; Donskaya, T.V.; Ernst, R.; Mazukabzov, A.M.; Sklyarov, E.V.; Pisarevsky, S.A.; Wingate, M.; Suderlund, U. Proterozoic basic magmatism of the Siberian Craton: Main stages and their geodynamic interpretation. Geotectonis 2012, 46, 273-288. [CrossRef]

49. Nozhkin, A.D.; Borisenko, A.S.; Nevol'ko, P.A. Stages of Late Proterozoic magmatism and periods of Au mineralization in the Yenisei Ridge. Russ. Geol. Geophys. 2011, 52, 124-143. [CrossRef]

50. Vernikovskaya, A.E.; Datsenko, V.M.; Vernikovsky, V.A.; Matushkin, N.Y.; Laevsky, Y.M.; Romanova, I.V.; Travin, A.V.; Voronin, K.V.; Lepekhina, E.N. Magmatism evolution and carbonatite-granite association in the neoproterozoic active continental margin of the Siberian craton: Thermochronological reconstructions. Dokl. Earth Sci. 2013, 448, 161-167. [CrossRef]

51. Gladkochub, D.A.; Pisarevsky, S.A.; Donskaya, T.V.; Ernst, R.E.; Hanes, J.A. Proterozoic mafic magmatism in Siberian craton: An overview and implications for paleocontinental reconstruction. Precambrian Res. 2010, 183, 660-668. [CrossRef]

52. Andreeva, I.A.; Kovalenko, V.I.; Kononkova, N.N. Chemical composition of the magmas (melt inclusions) of melilite-bearing nephelinite of the Belaya Zima carbonatite complex (Eastern Sayan). Dokl. Earth Sci. 2004, 394, 518-522. 
53. Minaeva, Y.A.; Egorov, K.N. Mineralogy and Petrography of a Kimberlite-Picrite Dike in the Northwestern Urik-Iya Graben, the Eastern Sayan Region. Geol. Ore Depos. 2009, 51, 565-576. [CrossRef]

54. Lavrent'ev, Y.G.; Korolyuk, V.N.; Usova, L.V.; Logvinova, A.M. Electron probe microa-nalysis of pyrope for nickel traces as applied to study of the geothermometry of peridotites. Russ. Geol. Geophys. 2006, 47, 1075-1078.

55. Ashchepkov, I.V.; Andre, L.; Downes, H.; Belyatsky, B.A. Pyroxenites and megacrysts from Vitim picrite-basalts (Russia): Polybaric fractionation of rising melts in the mantle? J. Asian Earth Sci. 2011, 42, 14-37. [CrossRef]

56. Travin, A.V.; Yudin, D.S.; Vladimirov, A.G.; Khromykh, S.V.; Volkova, N.I.; Mekhonoshin, A.S.; Kolotilina, T.B. Thermochronology of the Chernorud granulite zone, Ol'khon Region, Western Baikal area. Geochem. Int. 2009, 47, 1107-1124. [CrossRef]

57. Tappe, S.; Foley, S.F.; Stracke, A.; Romer, R.L.; Kjarsgaard, B.A.; Heaman, L.M.; Joyce, N. Craton reactivation on the Labrador Sea margins: 40Ar/39Ar age and $\mathrm{Sr}-\mathrm{Nd}-\mathrm{Hf}-\mathrm{Pb}$ isotope constraints from alkaline and carbonatite intrusives. Earth Planet. Sci. Lett. 2007, 256, 433-454. [CrossRef]

58. Skublov, S.G.; Tolstov, A.V.; Baranov, L.N.; Melnik, A.E.; Levashova, E.V. First data on the geochemistry and $\mathrm{U}-\mathrm{Pb}$ age of zircons from the kamaphorites of the Tomtor alkaline-ultrabasic massif, Arctic Yakutia First data on the geochemistry and $\mathrm{U}-\mathrm{Pb}$ age of zircons from the kamaphorites of the Tomtor alkaline-ultrabasic massif, Arctic Yakutia. Geochemistry 2020, in press. [CrossRef]

59. Lazareva, E.V.; Zhmodik, S.M.; Dobretsov, N.L.; Tolstov, A.V.; Schcherbov, B.L.; Karmanov, N.S.; Gerasimov, E.Y.; Bryanskaya, A.V. Main minerals of abnormally highgrade ores of the Tomtor deposit. Russ. Geol. Geophys. 2015, 56, 844-873. [CrossRef]

60. Ford, C.E.; Russell, D.G.; Craven, J.A.; Fisk, M.R. Olivine-liquid equilibria: Temperature, pressure and composition dependence of the crustal/liquid cation partition coefficients for $\mathrm{Mg}, \mathrm{Fe}^{2+}, \mathrm{Ca}$ and $\mathrm{Mn}$. J. Petrology 1983, 24, 256-265. [CrossRef]

61. McDonough, W.F.; Sun, S.S. The Composition of the Earth. Chem. Geol. 1995, 120, 223-253. [CrossRef]

62. O'Reilly, S.Y.; Griffin, W.L. A xenolith-derived geotherm for southeastern Australia and its geophysical implications. Tectonophysics 1985, 111, 41-63. [CrossRef]

63. Lindsley, D.H.; Dixon, S.A. Diopside_enstatite equilibria at 850-1400 ${ }^{\circ} \mathrm{C}, 5-35$ kbar. Science 1976, $276,1285-1301$.

64. Manuella, F.C.; Ottolini, L.; Carbone, C.; Scavo, L. Metasomatizing effects of serpentinization-related hydrothermal fluids in abyssal peridotites: New contributions from Hyblean peridotite xenoliths (southeastern Sicily). Lithos 2016, 2641, 405-421. [CrossRef]

65. Naumov, V.B.; Kamenetsky, V.S.; Thomas, R.; Kononkova, N.N.; Ryzhenko, B.N. Inclusions of silicate and sulfate melts in chrome diopside from the Inagli deposit, Yakutia, Russia. Geochem. Int. 2008, 46, 554-564. [CrossRef]

66. Giuliani, A.; Phillips, D.; Kamenetsky, V.S.; Goemann, K. Constraints on kimberlite ascent mechanisms revealed by phlogopite compositions in kimberlites and mantle xenoliths. Lithos 2016, 240-243, 189-200. [CrossRef]

67. Wyatt, B.A.; Baumgartner, M.; Anckar, E.; Grutter, H. Compositional classification of "kimberlitic" and "non-kimberlitic" ilmenite. Lithos 2004, 77, 819-840. [CrossRef]

68. Evensen, N.M.; Hamilton, P.J.; O'Nions, R.K. Rare-earth abundances in chondritic meteorites. Geochim. Cosmochim. Acta 1978, 42, 1199-1212. [CrossRef]

69. Nimis, P.; Taylor, W. Single clinopyroxene thermobarometry for garnet peridotites. Part, I. Calibration and testing of a Cr-in-Cpx barometer and an enstatite-in-Cpx thermometer. Contrib. Mineral. Petrol. 2000, 139, 541-554. [CrossRef]

70. Ashchepkov, I.V.; Pokhilenko, N.P.; Vladykin, N.V.; Logvinova, A.M.; Kostrovitsky, S.I.; Afanasiev, V.P.; Pokhilenko, L.N.; Kuligin, S.S.; Malygina, L.V.; Alymova, N.V.; et al. Structure and evolution of the lithospheric mantle beneath Siberian craton, thermobarometric study. Tectonophysics 2010, 485, 17-41. [CrossRef]

71. Ashchepkov, I.V.; Vladykin, N.N.; Ntaflos, T.; Kostrovitsky, S.I.; Prokopiev, S.A.; Downes, H.; Smelov, A.P.; Agashev, A.M.; Logvinova, A.M.; Kuligin, S.S.; et al. Layering of the lithospheric mantle beneath the Siberian Craton: Modeling using thermobarometry of mantle xenolith and xenocrysts. Tectonophysics 2014, 634, 55-75. [CrossRef] 
72. Ashchepkov, I.V.; Ntaflos, T.; Logvinova, A.M.; Spetsius, Z.V.; Vladykin, N.V. Monomineral universal clinopyroxene and garnet barometers for peridotitic, eclogitic and basaltic systems. Geosci. Front. 2017, 8 , 775-795. [CrossRef]

73. Ashchepkov, I. Single grain amphibole thermobarometer for mantle rocks. Geophys. Res. Abstr. 2017, 19, EGU2017-EGU3889.

74. Zheng, Y.-F. Subduction zone geochemistry. Geosci. Front. 2019, 10, 1223-1254. [CrossRef]

75. Watson, E.B.; Harrison, T.M. Zircon saturation revisited: Temperature and composition effects in a variety of crustal magma types. Earth Planet. Sci. Lett. 1983, 64, 295-304. [CrossRef]

76. Hermann, J.; Rubatto, D. Accessory phase control on the trace element signature of sediment melts in subduction zones. Chem. Geol. 2009, 265, 512-552. [CrossRef]

77. Perchuk, A.L.; Yapaskurt, V.O.; Griffin, W.L.; Shur, M.Y.; Gain, S.E.M. Three types of element fluxes from metabasite into peridotite in analogue experiments: Insights into subduction-zone processes. Lithos 2018, 302-303, 203-223. [CrossRef]

78. Hart, S.R.; Dunn, T. Experimental cpx/melt partitioning of 24 trace elements. Contrib. Mineral. Petrol. 1993, 113, 1-8. [CrossRef]

79. Kuzyura, A.V.; Litvin, Y.A.; Jeffries, T. Interface partition coefficients of trace elements in carbonate-silicate parental media for diamonds and paragenetic inclusions (experiments at 7.0-8.5 GPa). Russ. Geol. Geophys. 2015, 56, 221-231. [CrossRef]

80. Tomlinson, E.L.; Jones, A.P.; Harris, J.W. Co-existing fluid and silicate inclusions in mantle diamond. Earth. Planet. Sci. Lett. 2006, 250, 581-595. [CrossRef]

81. Nikiforov, A.V.; Yarmolyuk, V.V. Late Mesozoic carbonatite provinces in Central Asia: Their compositions, sources and genetic settings. Gondwana Res. 2019, 69, 56-72. [CrossRef]

82. Rollinson, H.R. Using Geochemical Data: Evaluation, Presentation, Interpretation; Longman: Harlow, UK, 1993; 290p.

83. De Paolo, D.J. Trace element and isotopic effects of combined wall rock assimilation and fractional crystallization. Earth Planet. Sci. Lett. 1981, 53, 189-202. [CrossRef]

84. Woolley, A.R. The Alkaline Rocks and Carbonatites of the World. Part I: North and South America; University of Texas Press: Austin, TX, USA, 1987; 216p.

85. Kogarko, L.N.; Kononova, V.A.; Orlova, M.P.; Woolley, A.R. The Alkaline Rocks and Carbonatites of the World. Part 2. Former USSR; Chapman \& Hall: London, UK, 1995; 226p.

86. Srivastava, R.K.; Chalapathi Rao, N.V.; Sinha, A.K. Cretaceous potassic intrusives with affinities to aillikites from Jharia area: Magmatic expression of metasomatically veined and thinned lithospheric mantle beneath Singhbhum Craton, Eastern India. Lithos 2009, 112, 407-418. [CrossRef]

87. Foley, S.F.; Andronikov, A.V.; Melzer, S. Petrology of ultramafic lamprophyres from the Beaver Lake area of Eastern Antarctica and their relation to the breakup of Gondwanaland. Mineral. Petrol. 2002, 74, 361-384. [CrossRef]

88. Secher, K.; Heaman, L.M.; Nielsen, T.F.D.; Jensen, S.M.; Schjøth, F.; Creaser, R.A. Timing of kimberlite, carbonatite, and ultramafic lamprophyre emplacement in the alkaline province located $64^{\circ}-67^{\circ} \mathrm{N}$ in southern West Greenland. Lithos 2009, 112, 400-406. [CrossRef]

89. Giebel, J.; Marks, M.A.W.; Gauert, C.D.K.; Markl, G. A model for the formation of carbonatite-phoscorite assemblages based on the compositional variations of mica and apatite from the Palabora Carbonatite Complex, South Africa. Lithos 2019, 324-325, 89-104. [CrossRef]

90. Amelin, Y.; Zaitsev, A.N. Precise geochronology of phoscorites and carbonatites: The critical role of U-series disequilibrium in age interpretations. Geochim. Cosmochim. Acta 2002, 66, 2399-2419. [CrossRef]

91. Lee, M.J.; Lee, J.I.; Garcia, D.; Moutte, J.; Williams, C.T.; Wall, F.; Kim, Y. Pyrochlore chemistry from the Sokli phoscorite-carbonatite complex, Finland: Implications for the genesis of phoscorite and carbonatite association. Geochem. J. 2006, 40, 1-13. [CrossRef]

92. Ivanyuk, G.Y.; Kalashnikov, A.O.; Pakhomovsky, Y.A.; Mikhailova, J.A.; Yakovenchuk, V.N.; Konopleva, N.G.; Sokharev, V.A.; Bazai, A.V.; Goryainov, P.M. Economic minerals of the Kovdor baddeleyite-apatite-magnetite deposit, Russia: Mineralogy, spatial distribution and ore processing optimization. Ore Geol. Rev. 2016, 77, 279-311. [CrossRef] 
93. Chakhmouradian, A.R.; Reguir, E.P.; Zaitsev, A.N.; Couslan, C.; Xu, C.; Kynick, J.; Hamid Mumin, A.; Yanga, P. A patite in carbonatitic rocks: Compositional variation, zoning, element partitioning and petrogenetic significance. Lithos 2017, 274-275, 188-213. [CrossRef]

94. Klemme, S.; Dalpe, C. Trace-element partitioning between apatite and carbonatite melt. Am. Mineral. 2003, 88, 639-646. [CrossRef]

95. Thomsen, T.B.; Schmidt, M.W. Melting of carbonated pelites at 2.5-5.0 GPa, silicate-carbonatite liquid immiscibility, and potassium-carbon metasomatism of the mantle. Earth Planet. Sci. Lett. 2008, 267, 17-31. [CrossRef]

96. Brod, J.A.; Junqueir-Brod, T.C.; Gaspar, J.C.; Petrinovic, I.A.; de Castro Valente, S.; Corval, A. Decoupling of paired elements, crossover REE patterns, and mirrored spider diagrams: Fingerprinting liquid immiscibility in the Tapira alkaline-carbonatite complex, SE Brazil. J. South Am. Earth Sci. 2013, 41, 41-56. [CrossRef]

97. Kjarsgaard, B.A. Phase relations of a carbonated high-CaO nephelinite at 0.2 and 0.5 Gpa. J. Petrol. 1998, 39, 2061-2075. [CrossRef]

98. Veksler, I.V.; Dorfman, A.M.; Dulski, P.; Kamenetsky, V.S.; Danyushevsky, L.V.; Jeffries, T.; Dingwell, D.B. Partitioning of elements between silicate melt and immiscible fluoride, chloride, carbonate, phosphate and sulfate melts, with implications to the origin of natrocarbonatite. Geochim. Cosmochim. Acta 2012, 79, $20-40$. [CrossRef]

99. Martin, L.H.J.; Schmidt, M.W.; Mattsson, H.B.; Ulmer, P.; Hametner, K.; Guenther, D. Element partitioning between immiscible carbonatite-kamafugite melts with application to the Italian ultrapotassic suite. Chem. Geol. 2012, 321, 96-112. [CrossRef]

100. Mitchell, R.H.; Dawson, J.B. Carbonate-silicate immiscibility and extremely peralkaline silicate glasses from Nasira cone and recent eruptions at Oldoinyo Lengai Volcano, Tanzania. Lithos 2012, 152, 40-46. [CrossRef]

101. Saha, A.; Manikyamba, C.; Santosh, M.; Ganguly, S.; Khelen, A.C.; Subramanyam, K.S.V. Platinum Group Elements (PGE) geochemistry of komatiites and boninites from Dharwar Craton, India: Implications for mantle melting processes. J. Asian Earth Sci. 2015, 105, 300-319. [CrossRef]

102. Rudnick, R.L.; McDonough, W.F.; Chappell, B.W. Carbonatite metasomatism in the northern Tanzanian mantle: Petrographic and geochemical characteristics. Earth Planet. Sci. Lett. 1993, 114, 463-475. [CrossRef]

103. Veter, M.; Foley, S.F.; Mertz-Kraus, R.; Groschopf, N. Trace elements in olivine of ultramafic lamprophyres controlled by phlogopite-rich mineral assemblages in the mantle source. Lithos 2017, 292-293, 81-95. [CrossRef]

104. Reguir, E.P.; Chakhmouradian, A.R.; Halden, N.M.; Malkovets, V.G.; Yang, P. Major and trace-element compositional variation of phlogopite from kimberlites and carbonatites as a petrogenetic indicator. Lithos 2009, 112, 372-384. [CrossRef]

105. Sharygin, V.I.; Doroshkevich, A.G. Mineralogy of secondary olivine-hosted inclusions in calcite carbonatites of the Belaya Zima alkaline complex, Eastern Sayan, Russia: Evidence for late-magmatic Na-Ca-rich carbonate composition. J. Geol. Soc. India 2017, 90, 524-530.

106. Panina, L.I.; Podgornykh, N.M. Melt inclusions in minerals of carbonatites Beloziminsky massif. Dokl. Earth Sci. 1975, 233, 1447-1450.

107. Andreeva, I.A. Carbonatitic melts in olivine and magnetite from rare-metal carbonatite of the Belaya 'Zima alkaline carbonatite complex (East Sayan, Russia). Dokl. Earth Sci. 2014, 455, 436-440. [CrossRef]

108. Nielsen, T.F.D.; Solovova, I.P.; Veksler, I.V. Parental melts of melilitolite and origin of alkaline carbonatite: Evidence from crystallized melt inclusions, Gardiner complex. Contrib. Mineral. Petrol. 1997, 126, 331-344. [CrossRef]

109. Kuzmin, M.I.; Yarmolyuk, V.V. Plate Tectonics and mantle plumes-the basis of endogenous tectonic activity of the Earth for the last 2 billion years. Russ. Geol. Geophys. 2016, 57, 11-30. [CrossRef]

110. Sirotkin, A.N.; Talovina, I.V.; Duryagina, A.M. Mineralogy and geochemistry of alkaline lamprophyres of north-western Spitsbergen (Svalbard). Geochemistry 2019, in press. [CrossRef]

111. Kravchenko, S.M.; Bagdasarov, Y.A. Geochemistry, Mineralogy and Genesis of Apatite-bearing Massifs (Maymeicha-Kotui Carbonatite Province); Nauka: Moscow, Russia, 1987; 127p.

112. Ashchepkov, I.V.; Alymova, N.V.; Logvinova, A.M.; Vladykin, N.V.; Kuligin, S.S.; Mityukhin, S.I.; Downes, H.; Stegnitsky, Y.B.; Prokopiev, S.A.; Salikhov, R.F.; et al. Picroilmenites in Yakutian kimberlites: Variations and genetic models. Solid Earth 2014, 5, 915-938. [CrossRef] 
113. Braunger, S.; Marks, M.A.W.; Wenzel, T.; Chmyz, L.; Azzone, G.R.; Markl, G. Do carbonatites and alkaline rocks reflect variable redox conditions in their upper mantle source? Earth Planet. Sci. Lett. 2020, 533, in press. [CrossRef]

114. Stoppa, F.; Schiazza, M.; Rosatelli, G.; Castorina, F.; Sharyg, V.V.; Ambrosio, F.A.; Vicentini, N. Italian carbonatite system: From mantle to ore-deposit. Ore Geol. Rev. 2019, 114, 103041. [CrossRef] 